The Fire of Desire: A Multisited Inquiry into Consumer Passion

Author(s): Russell W. Belk, Güliz Ger and Søren Askegaard

Source: Journal of Consumer Research, Vol. 30, No. 3 (December 2003), pp. 326-351

Published by: Oxford University Press

Stable URL: http://www.jstor.org/stable/10.1086/378613

Accessed: 29-08-2017 12:33 UTC

JSTOR is a not-for-profit service that helps scholars, researchers, and students discover, use, and build upon a wide range of content in a trusted digital archive. We use information technology and tools to increase productivity and facilitate new forms of scholarship. For more information about JSTOR, please contact support@jstor.org.

Your use of the JSTOR archive indicates your acceptance of the Terms \& Conditions of Use, available at http://about.jstor.org/terms 


\title{
The Fire of Desire: A Multisited Inquiry into Consumer Passion
}

\author{
RUSSELL W. BELK \\ GÜLIZ GER \\ SØREN ASKEGAARD*
}

\begin{abstract}
Desire is the motivating force behind much of contemporary consumption. Yet consumer research has devoted little specific attention to passionate and fanciful consumer desire. This article is grounded in consumers' everyday experiences of longing for and fantasizing about particular goods. Based on journals, interviews, projective data, and inquiries into daily discourses in three cultures (the United States, Turkey, and Denmark), we develop a phenomenological account of desire. We find that desire is regarded as a powerful cyclic emotion that is both discomforting and pleasurable. Desire is an embodied passion involving a quest for otherness, sociality, danger, and inaccessibility. Underlying and driving the pursuit of desire, we find self-seduction, longing, desire for desire, fear of being without desire, hopefulness, and tensions between seduction and morality. We discuss theoretical implications of these processes for consumer research.
\end{abstract}

$\mathrm{C}$ onsider a child's Christmas anywhere in the world that celebrates Santa and his avatars as magical gift-bringers. For such a child, desire is palpable, and hope hangs as heavily as stuffed stockings on the fireplace mantle. Yet most prior understandings of consumers do very little to encompass the excited state of desire that moves children and adults alike.

This is not to say that desire has failed to seep into or even permeate consumer research. In fact, many studies of consumption touch upon phenomena intimately related to consumer desire, even though an explicit development of the construct is still lacking in the consumer behavior literature. There is also spreading consensus that much, if not all, consumption has been quite wrongly characterized as involving distanced processes of need fulfillment, utility maximization, and reasoned choice. Studies debunking this perspective include those investigating impulse purchasing (Rook 1987; Rook and Hoch 1985), compulsive consumption (O’Guinn and Faber 1989), hedonic experiences (Hol-

*Russell W. Belk is the N. Eldon Tanner Professor in the David Eccles School of Business, University of Utah, 1645 E. Campus Center Drive, Salt Lake City, UT 84112-9305 (e-mail: mktrwb@business.utah.edu). Güliz Ger is professor of marketing at Bilkent University, 06800 Bilkent, Ankara, Turkey (e-mail: ger@bilkent.edu.tr). Søren Askegaard is professor of marketing at University of Southern Denmark, Odense, Campusvej 55, KD-5230, Odense M, Denmark (e-mail: aske@sam.sdu.dk). This article is truly a joint effort by the authors, to the extent that we often can no longer distinguish who wrote what. The authors wish to thank the reviewers, the associate editor, and the editor for their help and advice

More detailed color versions of figs. 1-7 of this article may be found in the electronic edition of $J C R$. brook and Hirschman 1982), ritual (Rook 1985), rites of intensification (Belk and Costa 1998), paradoxes of possession (Mick and Fournier 1998), sacralization (Belk, Wallendorf, and Sherry 1989), sacrifice (Ahuvia 1992), mystique (Schouten and McAlexander 1995), mystery (Belk 1991), temptation (Thompson, Pollio, and Locander 1994), flow (Celsi, Rose, and Leigh 1993), play (Holt 1995), magic (Arnould and Price 1993; Arnould, Price, and Otnes 1999), self-reward (Mick and DeMoss 1990), embodiment (Joy and Venkatesh 1994; Thompson and Hirschman 1995; Zaltman and Coulter 1995), vital energy channeling (Gould 1991b), transcendence (Sherry 1983), pursuit of the sublime (Holbrook et al. 1984), and fantasies, dreams, and myths (Levy 1986, 1999). All of these studies investigate processes closely related to consumer desire.

A sharp distinction between consumer desire versus needs or wants is evident in the way that we refer to these concepts in everyday language. In a conceptual paper, we observed that:

\footnotetext{
We burn and are aflame with desire; we are pierced by or riddled with desire; we are sick or ache with desire; we are tortured, tormented, and racked by desire; we are possessed, seized, ravished, and overcome by desire; we are mad, crazy, insane, giddy, blinded, or delirious with desire; we are enraptured, enchanted, suffused, and enveloped by desire; our desire is fierce, hot, intense, passionate, incandescent, and irresistible; and we pine, languish, waste away, or die of unfulfilled desire. Try substituting need or want in any of these metaphors and the distinction becomes immediately apparent. Needs are anticipated, controlled, denied, post-
} 
poned, prioritized, planned for, addressed, satisfied, fulfilled, and gratified through logical instrumental processes. Desires, on the other hand, are overpowering; something we give in to; something that takes control of us and totally dominates our thoughts, feelings, and actions. Desire awakens, seizes, teases, titillates, and arouses. We battle, resist, and struggle with, or succumb, surrender to, and indulge our desires. Passionate potential consumers are consumed by desire (Belk, Ger, and Askegaard 2000, p. 99).

Whether or not this rhetorical description of fighting or succumbing to consumer desire captures desire as consumers experience it is an issue addressed by the present study.

Based on our initial work with metaphors of desire in various languages (Belk et al. 1996) and with several projective instruments (Belk et al. 1997) and also on the studies cited above, we anticipated that we would find that consumers regard their desire as a hot, passionate emotion quite different from the dispassionate discourse of fulfilling wants and needs. Consumer desire is a passion born between consumption fantasies and social situational contexts. Consumer imaginations of and cravings for consumer goods not yet possessed can mesmerize and seem to promise magical meaning in life. Among the sorcerers helping to enchant these goods are advertisers, retailers, peddlers, and other merchants of mystique. But these magical systems of promotion (Williams 1980) and dreamworlds of display (Williams 1982) are not the only processes at work in bewitching us. Prior work also suggests that consumers willingly act as sorcerers' apprentices in window-shopping, daydreaming, television viewing, magazine reading, Internet surfing, word-of-mouth conversing, and an often not-so-casual observing of others' consumption (Belk 2001; Belk et al. 1997; Freedberg 1993). Just as advertisers help to enchant our lives as consumers, we hope to enchant our visions as consumer researchers by deriving an understanding of impassioned desire.

The basic question underlying this inquiry is what the bases are for passionate consumption aspirations. We are interested in the role played by consumers, marketers, and culture in this process. How is it that consumers do not feel satiated? If the consumer is not a victim of advertising and marketing but, rather, is an active agent, how is it that consumers cannot have enough? If, as Campbell (1987) suggests, consumer desire is a state of enjoyable discomfort, what makes it enjoyable, and what makes it uncomfortable? What sustains desires despite the discomfort, and what keeps them in check despite the enjoyment? If Campbell is wrong, what is a better way of understanding desire? How important is the cycle of desire suggested by Gould (1991a)? Is desire itself alluring? What of the distance suggested by Simmel ([1900] 1978), the mimesis suggested by Girard (1977), and the transgression suggested by Bataille (1967)? And, most significantly, how do all these factors come together to account for a seemingly endless procession of consumer desires?

As we shall see, all of these authors and many more have inspired and informed our work on consumer desire. We begin our inquiry with a look at prior research on passionate consumption and then proceed to a brief discussion of various perspectives on the notion of desire.

\section{PASSIONATE CONSUMPTION}

In studying "passionate consumption," we are not necessarily concerned with hedonic or aesthetic consumption in which goods and services are approached through "symbolic meanings, hedonic responses, and aesthetic criteria" (Holbrook and Hirschman 1982, p. 132). Nor do we focus on all aspects of high involvement consumption (e.g., Richins and Bloch 1986). Instead, we consider narrower questions involving objects and states of passionate desire. Although we might talk about degrees in the experience of desire due to variations in the will and capability to control desires, some kind of passionate consumer desire was a familiar feeling for nearly all of the participants in our research. Nevertheless, although consumer research has tapped other aspects of emotional consumption, it has not dealt with the core of passionate consumption characterized by desire.

\section{Prior Consumer Research on Passionate Consumption}

In the 1950s, Levy (1959) noted that consumption is becoming ever more playful. Recent work on passionate consumption in overtly playful contexts includes such activities as sky diving (Celsi et al. 1993), river rafting (Arnould and Price 1993; Arnould et al. 1999), buckskinning (Belk and Costa 1998), motorcycle riding (Schouten and McAlexander 1995), and baseball spectating (Holt 1995). But Levy's observation extends beyond play to find ludic activities in presumably more serious consumption pursuits. Levy's student, Rook (1987), investigated the related notion of impulse purchasing, defined as "a sudden, often powerful and persistent urge to buy something immediately" (p. 191). This definition shares the powerful urges characteristic of desire, but impulse purchasing is sudden and seeks immediate fulfillment. We sought to determine, in part, whether desires are sustained over longer periods of time. Likewise, the concept of compulsive consumption (e.g., O'Guinn and Faber 1989) shares something in common with the intense and powerful emotions of consumer desire. But the act of compulsive consumption may be more satisfying or relieving (of a state of anxiety) than is the purchase object itself, whereas with consumer desire it seems likely that the focal object of fervent longing is all important and that the state of desire is more pleasurable than the angst-ridden agitation that precedes compulsive consumption. Furthermore, we believe that, in a consumer society, desire elicits more mixed feelings than the opprobrium directed toward compulsive consumption.

Another related concept is consumer seduction by marketers (Deighton and Grayson 1995; Reekie 1993). Deighton and Grayson (1995) find that consumers are often complicit 
in their own seduction, and we sought to find whether this is also commonly the case with consumer desires. If, as MacCannell (1987) argues, consumer seduction borders on the act or fantasy of rape, complicit consumption could lessen the criticism of marketers as sly manipulators of the desires of an innocent public. In other formulations, it is the object rather than its marketer that is the seducer. Baudrillard (1983) concluded that "everything is reversed if we turn to thinking about the object. Here, it is no longer the subject who desires but the object that seduces" (p. 127). Seduction, he suggests, is a fundamental alternative to the rationality of contemporary society because it is rooted in everything that opposes rationality: destiny, magic, and passion. We examine whether consumer desire is experienced as being seduced, and if so, what roles various seducing agents play.

The present perspective on desire may also share something in common with the work on self-gifts or monadic gift giving, in which Western consumers are found to sometimes reward, console, or celebrate themselves with selfpurchased gifts (e.g., Mick and DeMoss 1990; Sherry, McGrath, and Levy 1995). But, although such purchases are likely to be deemed special and may involve premeditated wishes (Mick and DeMoss 1990), the act of self-gift purchase can sometimes take on a carefree character and, like compulsive consumption, the product itself can be secondary. In these respects, although the self-gift may sometimes be an object of desire, it need not be so esteemed by the buyer. Nevertheless, the self-reward theme of many selfgifts may well share something in common with consumer desire in terms of providing a moral rationalization for consumption. Consumers find various ways to moralize their consumption patterns in order to justify them as being necessary and decent (Ger 1997; Ger and Belk 1999).

Other related accounts focus on the pleasure, creativity, enjoyment, and fantasy of consumption that liberate desires (Firat and Venkatesh 1995). Such enjoyment may be important even for the poor. For example, Lehtonen (1999) finds that small pleasures and aesthetic judgments intermingle in the shopping of heavily indebted people. Miller (1998) finds that women shopping for family provisions often reward themselves with small treats. The democratization of desire in the West in the nineteenth century made the celebratory pleasure of consumer desire available to the masses (Leach 1993). It was during this period, Leach argues, that mass consumers could first seriously entertain consumption fantasies. Campbell (1987) suggests that, during a somewhat earlier period, consumers in Europe began to savor desire as an anticipatory pleasure. In his model, there emerges a vicious cycle involving anticipation, consummation, disappointment, and renewed desire for another object. We investigate whether desire is experienced as democratized and cyclic across the varied economic and social conditions of the cultures we studied.

A further desire-related process that may have emerged even earlier in the historic interaction between consumers and marketers has been termed sorcery (Levy 1960) or magic (Arnould and Price 1993; Arnould et al. 1999; Belk et al. 1989). We consider potential elements of sorcery, including consumer receptivity, rites, and formulas like those that constitute a magical experience (Arnould et al. 1999). We also consider the metaphor suggested earlier of consumers as sorcerer's apprentices. Consistent with work on consumer creativity (e.g., Arnould et al. 1999; Firat and Venkatesh 1995) and fantasies (Levy 1999; Rook 1988), this would be a more proactive role for the consumer than prior research has typically envisioned.

There has also been related work on consumer strategies and efforts to control emotional urges. In the context of impulse purchasing, Rook (1987) found a conflict between control and indulgence. Similarly, among the women they studied, Thompson et al. (1994) find a dialectical pull between being in control and being out of control in consumption activities. Further, various scholars have theorized the strategies consumers may use to control and resist temptations (e.g., Ainslie 1985; Hoch and Lowenstein 1991). This, too, is an area we sought to explore.

\section{Needs, Wants, and Desires}

We recognize the vernacular relationship among needs, desires, and wants. Based on prior treatments of need and desire, our choice to focus on the latter is an effort to highlight what we believe to be a more useful and conceptually rich construct for understanding contemporary consumer behavior. According to Freund (1971), although only certain things can physiologically satisfy certain needs, the imagination is far freer when it comes to desires. The concept of desire shows an infinite initial openness - anything can potentially become the object of desire. On the other hand, need demonstrates an initial closedness since the need is rooted in a lack of a certain category of objects. Although any object can come to be desired, as an experientially lived phenomenon, desire is focused on a specific something shaped by social and historical circumstance. It is a particular man, woman, car, house, shirt, or leisure experience that is desired, not just any other person, vehicle, shelter, garment, or experience. Furthermore, we concur with Baudrillard (1972) that needs tend to hide their ideological nature behind a naturalized facade.

Along with Baudrillard, we suggest that desire is a notion directly addressing the social character of motivation. Even though we also use need in colloquial speech when we realize that this need is a social one, the use of the construct of need tends to naturalize the social institution that positions something as needed and therefore natural. This naturalization invokes the biological roots of needs. On the other hand, we find that the notion of want is too reassuringly controlled by the mind for it to cover the passionate aspects of desire. Furthermore, a want is normally taken as an expression of a personal, psychological preference structure. As we shall argue below, we see desire as deeply linked to the social world, both through the mimetic process (Girard 1977) and through the pool of available value systems and lifestyles that constrain the freedom to desire-what Foucault (1984a, 1984b, 1985, 1986) called strategies of modern 
governance. Desire, then, directly addresses the interplay of society and individual, of bodily passions and mental reflection. With the risk of oversimplifying a set of complex notions, we present table 1 , which summarizes the main traits of our view of the differences between needs, wants, and desires.

Desire, then, only comes alive in a social context. Castoriadis (1975) refers to the imaginary as the fundamental ability to see in things something that they are not. But he also underlines that the imaginary cannot exist without the symbolic, that is, the social template for the imagination. We believe desire to be of a similar nature. People are always able to produce imaginations of a good (or better) life, imaginations that motivate them to actions that attempt to flesh out that imagination. These may be oriented toward the hope for a good harvest with a sacrifice to the gods in order to secure such an outcome, or the hope for a wonderful quality of life made possible by realizing a dream of a second home by the sea. We take desire to be such passionate imagining. But such motivations and the schemes of action are always social, That is, they are shaped by, and expressed in, a given social context. In modern societies, this fleshing out of desire often takes the form of consumption; hence, the notion of consumer societies and consumer desire.

\section{PRIOR PERSPECTIVES ON CONSUMER DESIRE}

\section{Desire: From Psychoanalysis to Anthropology}

One influential view of desire is the perspective of Jacques Lacan. Desire in psychoanalytic views is an unconscious longing for maternal love that was frustrated during childhood (Richardson 1987). To Lacan, we are our desire (Lacan 1992, p. 321). It is the source of our life energy. For both Lacan and Freud, sexual desire is the overarching source for other forms of desire. The libido (Freud) or the striving for jouissance (Lacan) is the force underlying all types of desire. Because the underlying desire cannot be fulfilled with substitute objects, the desire to fill the void of lost love is bound to fail. Our approach is especially informed by more recent psychoanalytic views that argue that desire exists as lack only if the thing that might fill that lack is socially esteemed and that emphasize the connections between the psyche and the social/ cultural (e.g., Born 1998; Elliott 1992).

Neo-Marxist critical studies contend that marketing cre- ates desires that drive capitalist consumption (e.g., Baudrillard 1972; Ewen 1976; Haug 1986; Slater 1997). In these views, branding, advertising, personal selling, packaging, display, and design create symbolic meanings for commodities and tempt consumers by promising them an enhanced identity. With the exception of Baudrillard, classical criticisms of consumption make an implicit or explicit distinction between true (basic, authentic) versus false (alienated) needs. Such formulations are bound up with the problematic distinction of utilitarian needs and necessities versus superfluous excess and luxury.

Douglas and Isherwood (1979) offer an alternative to the utilitarian theory of consumer needs that dominates economics (including the Marxist economic belief in false needs and false consciousness). They call this alternative the envy theory of needs: we want what others have. But to this Douglas and Isherwood add that societies have found various envy-controlling mechanisms, such as instilling a fear of others' envy. This, in turn, results in envy-deflecting mechanisms, such as redistributing wealth through symbolic feasts and other rites of sharing, relying on evil eye amulets as a protection against envy, and avoiding conspicuous consumption that invites others' envy. But there is evidence that, with the development of consumerism, envy control and avoidance mechanisms break down; rather than fearing others' envy, we begin to cultivate it (e.g., Belk 1997).

This points to the fundamental social nature of desire, entailing a modern form of what Girard $(1977,1987)$ called mimetic desire. In his view, our rival's desire alerts us to the desirability of the object. The basis for this competitive and emulative desire is a battle for prestige. Within the social logic of mimesis (Girard 1977) and distinction, the symbolic object is not so much a reflection of our desire for the object of consumption as it is our wish for social recognition. Mimetic desire contains an inversion of more traditional theories of conspicuous consumption as initially formulated by Veblen (1899). Whereas conspicuous consumption points to the consumer's search for the gaze of the Other, mimetic desire points to the consumer's gaze on the Other (Dupuy 1979, p. 86).

As Douglas and Isherwood (1979) also emphasize, the desire for marker goods helps define our belonging to one group rather than another. Wilk (1997) argues that we define our group affiliation not only based on what we desire and like but also based on what we dislike, find disgusting, and

TABLE 1

DESIRE VERSUS NEED AND WANT

\begin{tabular}{llll}
\hline \hline & Need & Want \\
\hline Initial state & Fixed & Open \\
Relation to object & Open & Open or fixed \\
Cartesian relation & Body & Mind & Open \\
Mode of expression & Necessity & Wish & Body and mind \\
Root & Naturalization of social & Personal preferences \\
& institutions & Strategy of modern \\
\end{tabular}


associate with other groups. He also introduces a dynamic social aspect to desire. What we desire today and regard as a marker of our in-group membership may become unfashionable, distasteful, and a marker of out-group membership tomorrow. Thus desires exist in a state of flux, and desire and disgust are sometimes perilously close to one another. If these ideas are correct, others' consumption patterns should be frequently referenced when consumers discuss their own desires.

Another factor that theoretically shapes what we desire involves the scarcity or inaccessibility of various possible objects of desire. To Georg Simmel (1978 ), we desire most fervently those objects that transfix us and that we cannot readily have. Objects' distance and resistance to our pursuit intensify our desire. And when we desire some object, Simmel says, "our mind is completely submerged in it, has absorbed it by surrendering to it . . . our psychological condition is not yet, or is no longer, affected by the contrast between subject and object" (1978, p. 65). As in Lacan's view, we become our desire. Simmel also specified that, while objects of desire seem to draw us powerfully to them, they are nevertheless a product of our imaginations that lend to them "a peculiar ideal dignity" (p. 67). MacCannell (1987) calls this process "perpetual near-desire" involving the suspension of the illusion that has transfixed us just as it comes within reach, assuring that the attractive commodity can never fulfill our desires. This conceptualization differs in a small but important way from Campbell's (1987) contention that desires are ultimately incapable of fulfillment because the objects of our desires can never be as fabulous as our imaginations have made them. MacCannell's illusion is punctured by its realization, while Campbell's consumer illusion is negated by the recognition that the object cannot live up to our image of it.

Drawing on Campbell, a specific conceptualization of the process of consumer desire has been offered by Gould (1991a). He begins with the Tibetan Wheel of Life, which he describes as involving a cycle of prana (desire), death, and rebirth, and he emphasizes consumer analogies to the Wheel of Life stages. Gould (1991a) specifies a consumption sequence in which object desire arises, money is sought to fulfill it, and the object is acquired and consumed. Postconsumption bliss brings the death of desire, leading to the rebirth of desire focused on a new object. Gould (1991a) specifies that the reproduction of desire is itself desirable, but he also acknowledges the Tibetan Buddhist goal of transcending material desire as an enlightened being. These stages differ from Campbell's work (1987) by specifying the achievement of "postconsumption bliss," even if fleetingly. We hope that our investigation of consumer accounts of their desire processes will help to clarify the role of accessibility, imagination, and realization of consumer desires during the course of consumer desire.

\section{Embracing and Controlling Desire}

Two theorists who argue that desire is linked to what could be called constructive transgression are Bataille (1967) and Bakhtin (1968). For Bataille (1967), excess is constitutive of society. Societies are created to bolster the aggressive tendencies inherent in the process of sharing life space; society is thus constituted by its interdictions. But, at the same time, the (potential) transgression of these interdictions is what raises the human being above the general collectivity and provides an individual with uniqueness. This potential, which Bataille refers to as sovereignty, is realized through transgressive consumptive activities. Bakhtin (1968) argues that a key function of medieval fairs and carnival periods was to provide an opportunity to transgress and resist the power of social institutions like the church by indulging in excesses of food, drink, sex, and the lures of the peddler. In modern consumer societies, pursuing these "lower order" passions is sanctioned at carnivalesque festivals, certain rites of passage, and holiday celebrations. So, besides the general social sanctions for the display and pursuit of desires in a consumer society, there are also authorized times, places, and activities where the pursuit of desires (of various sorts) and transgressive transformations are allowed to take place. These loci may be thought of as liminal or liminoid, in Victor Turner's terms (Turner and Turner 1978). We may also find liminal occasions for transgressive indulgence of our desires during tourism and in special shopping venues such as department stores and shopping malls that have historically created intoxicating sumptuous displays of exotic goods from elsewhere (e.g., Leach 1993; Williams 1982). Hence, desire states involve individual and social opposition between embracing and resisting objects of desire. Laborit (1976) notes that "drives and desires rejected by consciousness, because not in accordance with the cultural norms of present society, have always engendered both fear and curiosity for human beings" (p. 41). Although fear is the mechanism touched upon by social moralities, like the religious doctrines of sin and temperance that seek to curb self-indulgence, curiosity shows in the perverse delight by some in transgressing such social moralities (Sassatelli 2001). Accordingly, we would expect to find cultural differences in the times and places that the different cultures studied sanction as acceptable for the expression and indulgence of desires or, in other words, cultural variations in the morality and control of desire.

As Foucault $(1985,1986)$ has argued for sexual desires, humans have been concerned with the control of desires throughout recent history. Foucault's (1985) analysis reveals pervasive systematic efforts to control and inhibit longing as Christianity attempted to keep desire focused on God and the church. As Tiger (1992) notes, to control peoples' desires is to control the people themselves. Although some forms of Islam have had a somewhat more tolerant view toward desire, all major world religions have attempted to curb desires and inhibit their pursuit (Belk 1983; Belk et al. 2000). However, such forms of external control represent what Foucault (1984b) considers to be a premodern authoritarian exertion of power. Control can be self-imposed as well as externally prescribed. The modern subjectivity produces a more subtle form of power that is perceived as 
freedom. To do this, individuals must first come to feel that they have a free will, agency, a freedom to choose their lifestyle. This, in turn, requires that people "monitor their inner thoughts and desires" (Collier 1997, p. 25) in order to become the sorts of people they would like to be. This does not mean that they are really free agents, but it entails a felt agency, a particular (modern) self-construction, and self-presentation. In modernity, we have a choice of selves, but becoming a choosing self is not freedom but a strategy of modern governance (Foucault 1984a, 1984b, 1985, 1986). Constraints on desire, no longer imposed by traditional institutions, are now embedded in the range of social lifestyles available for the choosing self. Ironically, while this modern reflexivity ostensibly attends inner rather than outer perceptions of what others expect of us, it involves an internalized, and thus even more effective, acceptance of nonimposed social morals.

In the domain of sexual desires, Foucault sees self-restraint as internalized social control (Foucault 1984a, 1985, 1986). Subjects choose to restrain themselves in order to pursue what they believe to be happiness, purity, and wisdom, practices varying in different societies and times and involving dieting, physical exercise, and other forms of self-control (Foucault 1984a, 1986, 1988a, 1988b). Self-control, however, need not only involve reigning in desires; it can also involve nurturing desires, for instance, to become a home owner, an erudite playgoer, or a dedicated sports team fan. Such self-governance shapes and works through choices and desires (Thompson and Hirschman 1995).

Related formulations focus on the inhibition or curbing of the pursuit of desires by arguing and bargaining with ourselves in order to keep from carrying out wishes that are regarded as indulgent (e.g., Ainslie 1985; Baumeister 2002; Hoch and Lowenstein 1991). As Elliott (1997) argues, the field of desire is torn by conflicting urges toward control and freedom. We live our daily lives in a balancing act between social encouragements to both indulge and control desires through inner personal cravings and inhibitions, more or less successfully resisting and controlling our consumer desires. In terms of material consumer goods acquisition, a lack of restraint can become an impulse control disorder resulting in compulsive consumption (e.g., O'Guinn and Faber 1989).

A further theoretical variation on embracing versus renouncing desires emerges from the specification of the bodily basis for desire. By making material passion a vice, a society can make consumer desire a sin or an unacceptable transgression from which we must seek to purify ourselves (Falk 1994). In Western society, a transformed Calvinist ethos makes the disciplined body a reflection of a strong work ethic and God's grace (Thompson and Hirschman 1995). A dual standard makes this imperative especially binding on women (Joy and Venkatesh 1994), who, in the realm of food, are pressured to resist tempting but supposedly fattening foods (Thompson and Hirschman 1995). In health care, more generally, folk beliefs about staying healthy often counterpose a restrained and disciplined body versus a lax and indulgent body (Crawford 1984).

Social control of consumer desire, either in the form of external control or self-control, is thought to decline in a consumer society. Furthermore, a globalizing ethos of consumption promotes consumer desires and objects of desire (Appadurai 1990; Ger and Belk 1996; Hannerz 1996; Miller 1995). A renunciation of curbs on envy provocation and desire is most clearly hypothesized as a desire to desire (e.g., Lefebvre 1991; Sontag 1979). That is, desire is no longer a sin or vice but an attractive and sought after state of being.

Campbell (1987) describes contemporary imaginative hedonism as involving "a state of enjoyable discomfort" ( $p$. 86) rooted in the Romantic Movement. Campbell also suggests that middle-class parents who teach their children to delay their gratifications in order to pursue longer-range goals are really heightening imaginative desire for the postponed pleasures. Thus, globalizing consumerism in global modernities moderates the control of consumer desires: "But the exclusive focus on the body may misread the source of our desires because: The human body is a cultural body, which also means that the mind is a cultural mind. The great selective pressure in hominid evolution has been the necessity to organize somatic dispositions by symbolic means. It is not that Homo Sapiens is without bodily 'needs' and 'drives,' but the critical discovery of anthropology has been that human needs and drives are indeterminate as regards the object because bodily satisfactions are specified in and through symbolic values" (Sahlins 1996, pp. 403-404). Thus we find different foods delicious or disgusting based on our culture more than our individual physiological or psychological reactions (Wilk 1997), echoing Girard's (1977) concept of mimetic desire. And it suggests another avenue for justifying our pursuit of desires by claiming that many other people desire the same thing, so it must therefore be worthy of our own desire.

Thus, the present study, in addition to considering the nature of desire, its potentially cyclical character, and the inhibition of desire by society or individuals, will try to untangle the social origins of, and constraints upon, consumer desire as far as the framework of our individual-based data permits. This ends our brief review of prior thinking about desire. The literature reviewed points to differences between desires and needs and to the social nature of desire, including mimesis, distance, transgression, social control, imaginative hedonism, legitimation, and the interplay between the body, psyche, and culture. But these discussions are at the conceptual or philosophical level, and they are not always specific to consumer desire. In the last half of the twentieth century, many works have addressed the political economy of desire. This has involved a variety of perspectives, such as critiques of consumer society, the role of advertising, and capitalism. These efforts, although far from having exhausted the depths of consumer desire, are today part of the canon of literature on consumer culture. However, it can be noted from the concepts reviewed that a phenomenological account of consumers' experienced de- 
sire-of what it feels like to desire and how we think about desire-is strikingly absent. For such a potentially central concept to consumer behavior research, we find this to be a fundamental and glaring omission. Our purpose and primary research goal is to provide such an account. Our focus is on the thoughts, feelings, emotions, and activities evoked by consumers in various cultural settings when asked to reflect on and picture desire, both as their particular ideas of a general phenomenon and as lived experiences. Our hope is that such an approach also can help shed new light on macro issues involving the growth of consumer society.

\section{METHODS}

We employed a variety of qualitative and interpretive methods in the present study. Our data were collected in urban environments in Ankara (Turkey), Copenhagen and Odense (Denmark), and Salt Lake City (United States). Our main intent in choosing these three contexts was to avoid the narrow confines of a single, usually U.S., context by pursuing a multisite project. The choice of sites allows for stability or differences in findings across New World versus Old World, established versus transitional markets, Christians versus Muslims, and social welfare systems versus an individualistic market-based system.

We started with advanced undergraduate and MBA students trained in qualitative methods through qualitative research methods classes, comprehensive consumer behavior classes, or a combination of both. The participants of the study first completed journals describing their specific experiences in desiring things (tangible possessions, experiences, and persons or pets) that they either did or did not acquire. We asked them to tell us their personal stories involving something they desired, currently or in the past, reflecting on how their desire arose; how it changed over time; what they felt, thought, and did; whether there were any particular people, things, or events that affected this desire; and so forth. Each student then completed from two to three semi-structured depth interviews with others (largely nonstudents) about a similar agenda of topics. The interviews generally lasted between one and one and a half hours. A few were considerably longer. Other students completed a series of projective tasks involving consumer desire, as described in Belk et al. (1997). The projective exercises involved collage construction (see figs. 1-7), fairy tales, synonyms and antonyms of states and objects of desire, associations with swimming in a sea of desired things, metaphoric sensory portraits (taste, smell, color, shape, touch, sound, emotion) of desire and its opposite, and drawings of their images of desire and the opposite of desire. In addition, we analyzed common metaphoric expressions of consumer desire in each of these cultures, with the analysis appearing in Belk et al. (1996). The present analysis is based on the entire data set. We report the nationality (TR, DK, US), sex $(\mathrm{M}, \mathrm{F})$, and age of informants where we quote material.

The total numbers of journals, interviews, and projective sets completed were 36, 90, and 29, respectively, in Turkey; 24, 34, and 72 in Denmark; and 49, 141, and 38 in the
United States. In each case, the number of males and the number of females were approximately equal. More than $80 \%$ of the student-conducted interviews were with nonstudents: 58 out of 90 interviews in Turkey, 17 out of 34 in Denmark, and 140 out of 141 in the United States. Even though those interviewed included people of various ages, professions, and social classes, they were most often young and middle class. Given that valuation of consumption as a potential means of fulfillment is negatively correlated with age and peaks in the mid-20s (e.g., Belk 1985; Csikszentmihalyi and Rochberg-Halton 1981; Richins and Dawson 1992), the youthful sample seems quite appropriate to a study of passionate consumer desire but also leads to a predominance of certain categories of desired objects over others.

We found the projective and metaphoric data to be very rich in capturing fantasies, dreams, and visions of desire. The journal and depth interview material was especially useful for obtaining descriptions of what and how desire was experienced. Although this is useful data, especially concerning the things people desire, it also showed some evidence of repackaging in more rational-sounding terms. Some informants found it difficult to elaborate on their private desires or did not want to reveal these desires. Hence, the projective measures sought to evoke fantasies, dreams, and visual imagination in order to bypass the reluctance, defense mechanisms, rationalizations, and social desirability that seemed to block the direct verbal accounts of some of those studied.

We are aware of the problems of cueing the informants directly on consumer desire, since desire may not be part of the vocabulary that consumers use to categorize their lived experiences. However, when cued on desire, almost all informants responded immediately and talked about consumption desires and the desired objects. They also freely associated desire with other constructs such as admiration, intense wanting, and longing. We take our informants' descriptions and projections as the best way they are able to account for their feelings and thoughts on consumer desire. The basic terms on which these accounts focused translate well across the three cultures, including at least a good part of the connotative universe around the terms. For instance, in Turkish, desire $=a r z u$, want $=$ istek, need $=$ ihtiyaç and gereksinim, and wish = dilek; in Danish, desire = begar, want and wish $=$ onske, and need = behov.

Even though our findings are specific to the three sites and cultures, they are meant as a way of broadening the scope of our data rather than as a basis for cross-cultural investigation. Both similarities and differences were found across sites. We found that many of the differences were more in emphases and specifics than in essential content. Our findings are, of course, specific to the cultures and people studied. The analyses were conducted iteratively, proceeding from independent analyses by each researcher in his or her home culture, followed by several meetings and comparisons. This gradually concentrated the initially very long list of themes prior to the final reanalysis using 
jointly constructed categories of meaning. This permitted us to focus on the broader themes, capturing the lived experience of informants' consumer desire as modern subjects in a consumer society while still retaining a consciousness of the different cultural contexts for such experiences of desire.

\section{FINDINGS I: THE PHENOMENON OF CONSUMER DESIRE}

Our findings are divided into two parts. We begin by describing the character of desire as felt by our informants and then turn to the process of consumer desire. The former part of the findings section deals in more detail with specific objects of desire as well as specific feelings attached to the experience of desire. This part is, therefore, also where most of the discussion of the cultural context of desire takes place. The latter findings section addresses more general aspects of desire as a process, aspects found in all the three sites of investigation included in this study. Following the two findings sections, we outline the interplay of seduction and morality in consumer desire and consider implications for consumer behavior theory.

\section{Embodied Passion}

Desire is experienced by our informants as an intense and usually highly positive emotional state best characterized as passion. Collages from the projective exercises depicting desire emphasize exotic and luxurious travel destinations, sexy and desirable people, couples dancing or embracing ardently, passionate activities such as bullfighting, and luscious and delicious foods and beverages. As is also characteristic of the metaphors elicited for desire, the collages emphasized lust, hunger, thirst, and dreamlike fantasies (Belk et al. 1996). When we desire, we visualize an exciting world of wonder, as accounts such as these reveal:

Desire is a thundering feeling. Desire is not something you daydream calmly about, it is something that makes you very alert-you can feel it all over your body (DK-M, 24).

When I was 14-15, I saw two pairs of earrings while shopping for a gift for my sister. Both were replicas of old Greek coins. . . . I was excited. I had always been fascinated by ancient Greece-from trips to ancient sites with my dad. I used to admire his knowledge and the white marble and the amazing sculptures. Now I was looking at the shop window with the same admiration. The earrings promised me antiquity. If I bought them, I'd be holding something from that world. I can't remember for how long I stared at the shop window. . . . I had money, but buying the earrings meant not having money to buy the gift for my sister. I left the store. I walked for a while without seeing anything. I wanted those earrings, I had to have them, I had to hold them, and watch them again and again when I wanted. I did not understand my feelings. Passion for a material thing was a foreign feeling for me.
But, I was holding the money tight and burning to buy them. (TR-F, 24)

I wanted this car so bad I could taste it! I could hardly function throughout the day because I would make myself sick thinking about the Honda and how bad I wanted it. (US-M, 26)

The last two narratives of longing are culturally conditioned as well as self-stimulated. Although the Honda image was nurtured by marketing activities, the passion for the earrings is instead based on the woman's recollection of interpersonal experiences with her father. But both instances are presented as a self-monitoring internal dialogue within these modern subjects.

Phrases such as "you can feel it all over your body," "burning to buy," and "I wanted this car so bad I could taste it" express bodily feelings. Sexual metaphors were also invoked in expressing what it feels like to desire. One informant drew a horse as her metaphorical expression of desire and explained:

I see desire as being like a stallion. I am completely crazy about such a large, beautiful stallion, large and sweaty when it really shows off. Particularly, and this may sound stupid, when they are rutting and completely-oh!- - they are somehow filled with so much passion. I find it incredibly amazing that their feelings flow from their bodies. Spontaneously, in some way. (DK-F, 23)

Craving was a frequently used synonym for desire steeped in embodied feelings. For example, a 30-year-old Turkish woman, talking about the coat she craved, explained that on five different days she tried the coat on, looked at herself in the mirror, and caressed it. Collage images such as dancing passionately and jumping dolphins (fig. 1) were explained in terms of the pleasurable bodily sensations of desire. Intense desire is a palpable feeling that permeates our existence-including our body-and rivets our consciousness on the desired object.

We can see in such accounts the interplay of imagination and bodily feelings in fueling the fires of desire. Fires of desire is an image that emerged from projective metaphoric portraits of desire as a taste, smell, color, shape, texture, and sound. Common responses included red, passionate, and hot, as well as smooth, soft, silky, round, and fragrant. The same associations for the opposite of desire included bland, black, gray, angular, square, coarse, loud, sour, and rotten. Contrasting desire with want, informants told us that desire was far more intense, profound, and powerfully motivating and that it is unintentional, unplanned, illogical, and may be accompanied by mistakes and irrationality. Because desire has to do with fantasies, it takes on a mystical, childlike, or enrapturing quality that is felt to be antithetical to reasoned calculation (Belk et al. 1997). Informants used phrases such as "I cannot live without," "will die for," "am obsessed 


\section{FIGURE 1}

TURKISH FEMALE DESIRE COLLAGE

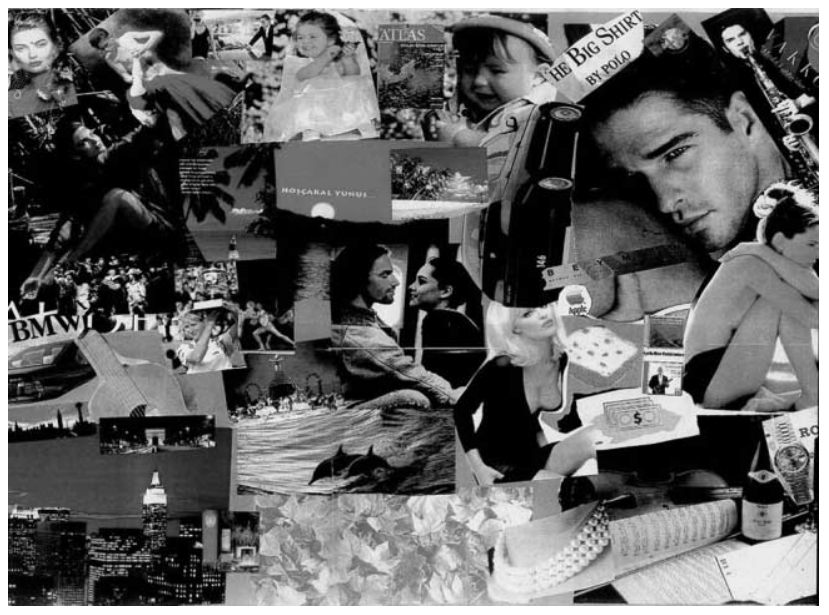

NOTE.-See the electronic edition of the journal for a color version of this figure.

with," "dream about," "cannot sleep thinking about," and "am crazy about" the objects of their desires.

Even though desire is an overwhelmingly positive emotion, it can also be unpleasant, as when it takes on an addictive character. Related to the addiction metaphor used by the informants were words such as "seized," "captured," "enslaved," "stupefied," and "bewildered." Addiction involves a strong appetite, devotion, obsession, and dependence (Belk et al. 1996). Such appetitive craving points to another role of the senses, coupled with imagination, in constituting desire. Even when the object desired has a partially negative character, like cigarette smoking (e.g., Klein 1993), the condition of craving still anticipates a positive state where things will be better. In this case it is more a matter of acting against our better judgment because of the strength of our reason-opposing desire: a phenomenon that Aristotle called akrasia (Stocker 1986).

So the fires of desire can potentially warm or burn the body. The power and passion of desire can feel life affirming, energizing, and invigorating, as well as potentially addictive and destructive. This dialectical tension cannot be resolved by reason, rationality, calculation, planning, and intention formation, at least not without killing desire in the process. The irrationality of desire and the seduction generated by the imagination and the senses permeate the object of desire and seemingly infuse it with tempting mythical power.

However, the intense embodied imaginative experience of consumer desire was not equally available to all those studied. Within Turkey, some of the older and lower-income informants felt that they could not entertain desires. Some such informants reacted to the question of desire with perplexity. For example, a technician said,

Desire? Nooo. We don't really know how to live. Because we came from the country. We left the village and came to the city. We still go back and forth: go to the village and work at the fields, come back to the city and work here. We have not seen anything else. (TR-M, 35)

Here desire is seen to involve having a life as a modern subject. Some focused on the impossibility of their dream. For example, a doorman, living in the basement of the building he tends to, said,

I desired a car once, but gave up on that dream. Where will $I$ go? My work is right here. How much would it cost to go places? The gas, the parking. People have lots of dreams, right? I have dreams too: to bring up my children well, to have them get a good education, to have a job that pays well; to have a house; to have each of my children have a house too. It is a good feeling to have all these dreams, a great joy, a beautiful feeling. (TR-M, 43)

The overriding sense of familial duty expressed above is also seen in the account below:

I also desire a car, but one has to think of the family first. So, a house. Besides, people are not in a situation to desire many things. I mean your average person. We live in Turkey, you know. I am very sad that we don't have a house. What can I do, we don't have one. Allah will give us one, inshallah. I hope Allah helps us just as he helps others. (TR-M, 33)

This man, like the technician's "we" in the first quote, expressed the perhaps comforting feeling that the inability to have desires is common for many in Turkey. His account also illustrates the reliance on the will of Allah (inshallah) that accompanies the downplaying of desires. Such accounts exemplify a felt impossibility of attaining the object and/or a self-impression of modesty, surrender, and gratefulness to and faith in God's will.

These informants, feeling the pressure of severe financial or family/social constraints, present a pragmatic attitude toward consumer desire. With consumer desire beyond hope, some feel that they do not have a life. But, rather than despair, they construct desire itself as unrealistic for themselves as well as many others like themselves. These are also voices not only of poverty but also of a duty-first mentality. Such a mentality reflects the Islamic notion of God's will and the traditional cultural emphasis on the family, downplaying the individual, free will, and choice. This is in contrast to modernity's focus on individual self-creation and choice (Foucault 1984b).

In contrast, more modern younger urbanites in Turkey, despite low incomes, felt that they can and do have strong individual desires. Desire was neither unknown nor entirely repressed among the older and rural informants, but it was muted, indicating that feeling entitled to desires requires a sense of independent will and agency. Similarly, Collier (1997) describes "moving from duty to desire" in interpersonal relations, with the development of modern subjectivities in rural Spain. Modern subjectivity, self-constructed and self- 
presented, involves a reduced respect for social convention and an increased respect for choice and personal freedom to act as one pleases. This also accords with Freund's (1971) notion that desire involves subjectivity, that is, choice. Thus, modern subjectivity is one that is ready to pursue the human potential of desire, channeled onto consumer objects within global and local consumer cultures, consumerist ideologies, and the global ethos of consumption.

Our findings indicate that passionate desire is available, but not necessarily accessible, to all. Rather than Leach's (1993) "democratization" of desire, which implies affordability, a better understanding is provided by the notion of modern subjectivities in consumerist global modernities. Global modernities provide the common background for different emphases in the experiences of desire, as well as different constructions of otherness and moralities in the sites we examined.

\section{Desire for Otherness}

The passion of embodied emotion is intense because the desired object or experience promises a transformation, an altered state. For informants from all three cultures, a fundamental appeal of desires lies in the promise of escape or alterity. Themes of magic and mystery are replete in the projective results, pointing to the transformative power of desire and the desired object. Hence, desired objects are sometimes worshipped and the consumer is bewitched by them. Fantastic and heroic figures such as Batman, Peter Pan, Cinderella, and Robin Hood appear in collages along with references to mythological phenomena such as mysterious golden masks and Stonehenge (fig. 2). The anticipated transformation can be to the past, the future, or another place, all of which offer escape from present conditions. As seen in the account of the Turkish woman's desire for the ancient Greek coin earrings, the imagination that is central to desire can sometimes be a fantasy that rekindles intense emotional experiences from the past (in this case, her experiences traveling to ruins with her father). There appears to be an attempt to recreate our image or recollection of a prior state of bliss, often associated with childhood. This is evident in comments such as these:

I always wanted a cabin. When I was a little girl, Nanni and Poppi had a cabin up in the mountains. . . . We would go up to this cabin, and play with all of my cousins. It had a little bridge that went across the creek. It had an old woodburning stove, and that's where we would cook everything. No bathroom, just an outhouse. This is where I always went, and we would play hide and seek with all of the cousins. And it was such good memories, I remember specifically walking down to what is now called Crompton's, and getting orange Popsicles. . . . I really loved it, so one thing I always wanted growing up was a cabin. . . . After I got married it was something I really wanted. (US-F, 49)

I do have many fantasies. I imagine a two-storied house by
FIGURE 2

TURKISH FEMALE DESIRE COLLAGE

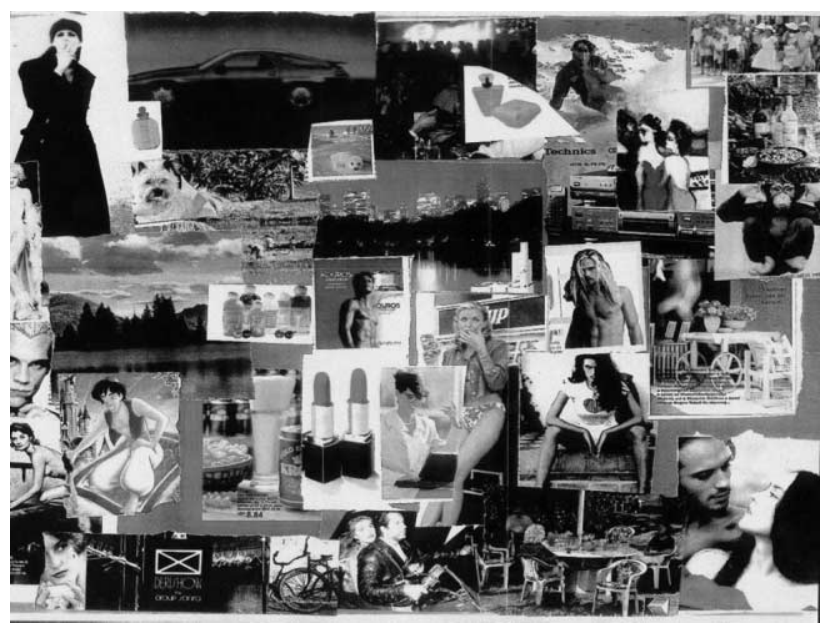

NotE.-See the electronic edition of the journal for a color version of this figure.

a forest among trees-clean, a well in the garden, as in films. We live in a flat-noise from above and below, not enough sun. If we turn the music on high, the neighbors complain. I grew up in a house with a garden, fruit trees. I miss it. When we lived in a house, my parents wanted a flat. Things change. I miss the past. (TR-M, 35)

Every summer since I started walking, I have been vacationing in a summer house. Four years ago, this opportunity stopped, and I could no longer experience beach and sea (other summer houses are no good!). To compensate for this loss of beach life, I needed a substitute. I started to look around for a big aquarium with lots of water and many different kinds of fish. It would provide a hint of the real thing. Furthermore, I would arrange a corner with some plastic plants and a little sand to set the aquarium up in. Nobody understood my desire. "Crazy," they said. My girlfriend also said "no." I never acquired the aquarium, but I haven't given up the idea. (DK-M, 46)

This is the type of longing identified by Stewart (1984) as nostalgia. As Holbrook (1993) found, nostalgia is often focused on life during adolescent years. In the context of consumer desire, this nostalgia focuses on a particular object of longing that encapsulates a remembered past that offers a dramatic contrast to the present.

For other informants, the stimuli for nourishing desires for other times were movies and books. In each case the desire is to escape to something far better, to a life diametrically opposed to the one currently being lived, to a condition of sacredness that transcends the profane present. The otherness of this experience is elaborated in such a way that it becomes the antidote to a dull, odious, or boring 
quotidian existence. Both otherness of the past and otherness of the future are resonant with McCracken's (1988) concept of displaced meaning, in which values too fragile to stand up to our current life situations are vested in past or future images condensed into a sought-after consumer good or experience.

In addition to the otherness of past or future time, the otherness of a place is also associated with certain objects of desire. These desires involve traveling to exotic places, living in other countries, enjoying the exciting nightlife of glamorous world cities, or just having a flat instead of living with parents. For an American woman who teaches karate, her desire is to experience Japaneseness:

\begin{abstract}
When I first started to do karate, I liked the pictures of famous martial artists, in these romantic settings, and stuff. So I fell in love with the Japanese style of architecture. Like flower arranging and art and stuff, so I guess it started when I first started taking karate. But I never put it in the framework of wanting my own dojo (a house to practice and teach martial arts) until I started teaching. . . . The art of frugality, simplicity, they are masters of form over function. Everything about the Japanese art and aesthetics appeals to me. . . . That I could do that stuff. The calligraphy on the walls, a little Zen garden outside, bonsai trees. A place where I could, ah, experience. A place where you could be at peace, a place where you could excel. I would love to have a place like that, not just inside the dojo, but a formal Japanese garden outside, a gazebo. (US-F, 38)
\end{abstract}

A major difference in the otherness of place desired by Turkish versus American and Danish informants was the complexity versus simplicity of that otherness. Urban symbolism was more noticeable in the collages of the Turkish informants. Pictures of world cities, such as New York with its high-rises and glittery skylines, as well as explanations of the luxurious, thrilling, and exciting nightlife in glamorous Western cities, were prominent. This was also apparent in voiced yearnings for the "glittery life of Barbie" and the colorful Singles lifestyle as seen in the TV series of that name. In Turkey, with the increased urbanization of the past 15 years, living in apartment buildings is a highly desirable sign of being modern and urban (Öncü 1997). Urban life, and particularly urban life in grand Western cities, is highly alluring. This Turkish man's desire for otherness seeks greater complexity - a more civilized life, seen to exist on the other side of the Mediterranean:

I took French lessons. The French are more modern, gentle, polite, fun loving, and joyous than Germans. They are Mediterranean, like me, but with culture and art that I can't find here. The Riviera is at the very center of the Mediterranean culture that I also am a member of. I realize that Turkey will never have such cultural richness, and that Turkey is becoming a false, cheap American copy. A life there would be so much more colorful. I say the Riviera because I imagine being able to go to the operas I could never go to in Turkey at La Scala, watching a soccer game at San Siro, in a civilized way, with no police surveillance or pressure, drinking the best wines of the world. . . . Even their women are beautiful like our Izmir women. I want to live the Mediterranean, its culture and art, in its center, where it was born. . . . I will do it one day, after I make some money. (TR-M, 25)

The desire here is to break away from the failed past (rural, traditional, poor) to become modern and to live like the Westerners seen in television, films, and magazines (Ger 1997).

In contrast, Danish and American collages have more scenes of nature, and accounts focus on things like "a cabin up in the mountains" and "great experiences of nature, water, and beach; sailing, playing in the forest." One Dane (F, 22), in a thinly veiled autobiographical fairytale, talked about a career woman "rescued" from her stressful life oriented toward money making and materialism by a "down-to-earth" type of man. Unlike Turkish desires for a more complex and exciting life, the American and Danish informants desire an otherness that has greater simplicity (as with the American woman desiring Japaneseness) or lifestyles that have a back-to-nature character. Still, each constitutes otherness from the perspectives of the informant.

Another major difference was the total transformation desired by some of the Turkish informants who want to become the Other. As in desiring to migrate to a Western country or to marry a modern German spouse, this desire for an essential conversion is linked to negative feelings about their current existence or likely future. In such cases, the desire is for a totally new self and life, beyond a casual playful encounter with the exotic Other, and this implies a fundamental and permanent escape. Together with the urban symbolism discussed above, to Turkish informants, the desired metamorphosis in becoming the Other involves a longing to be free, modern, civilized, and Western. Such desire for a fundamental otherness accords with the discourses of modernization and Westernization in Turkey. This desire for total transformation is consistent with the older and rural lowerincome informants who feel that they cannot entertain desires that are seen to be associated with having a life and the underlying modern subjectivity. It also shows the extremity the desire for otherness can reach in some cultures.

\section{Desire for Sociality}

Relationships. A characteristic of desire experiences that came through most clearly in several projective exercises is that desire is overwhelmingly underwritten by interpersonal responses from other people. For example, one exercise asked people to imagine themselves swimming in a sea of things that would bring them the greatest pleasure. The things most often envisioned were people, including family, friends, loved ones, and (for some men) nude women. The feelings that these others were seen to provide included being soothed, supported, excited, sexually aroused, and loved. In addition, anticipated feelings of joy, comfort, relaxation, harmony, warmth, tranquility, and nostalgia were reported. Fairy tales 
from projective exercises also suggested that the object of desire often facilitates the creation and maintenance of social relationships with family and friends.

In the collages, many pictures involved being and doing things with others, such as having beer, wine, and food with friends or family; doing sports; or traveling with people. These pictures were explained as depicting fun, sociability, and coziness, and as sharing exciting, enjoyable, and exotic experiences with others. It seems that an underlying motivation behind even our most object-focused desires is having social relationships with other people and obtaining desired responses from other people. Many stories entail the desired object as a means of building friendships, relationships, and sociability, such as the following:

When I was a kid, my parents and relatives took me to a nightclub. They all were drinking lemonade (the cheapest drink at the time) while watching the show. I wanted a glass too. . . . But it was [not] a lemonade that was my desire. My desire was having a lemonade with my family, while watching the show, just like everyone else. (TR-M, 60)

Thus, desire, which is felt so internally, is ultimately social. The object of desire is hoped to facilitate social relations, joining with idealized others, and directing one's social destiny. A similar goal is seen in the marker goods defining group membership, discussed by Douglas and Isherwood (1979), and in consumption objectifying sociability and relationships of love, discussed by Miller (1998).

Mimesis. Desire initiated by observing others' consumption accords with Girard's (1977) notion of mimetic desire. People emulate others either in order to be like them or to undo or reverse their envy of these others. Several informants explicitly pointed to mimetic aspects of their desire.

Over time, my desire to own a mountain bike greatly increased as my friends went on biking trips to Moab. Upon [their] returning from a three-day trip, I was invited to see slides and pictures they took on their trek through Slick Rock. . . . I found myself wanting to experience the same thrills and beauty I saw and heard about from my friends. (US-F, 30)

Not so long ago I desired a jacket, not just any jacket but a specific leather jacket. I needed it for special occasions, and it had to be a leather jacket. I think that was the case because everybody else wore those, and they looked really good. That is why I also had to have one. (DK-F, 22)

I was a child during the years of WWII. My parents bought me a pair of tie-up boots. . . . All my friends had rubber boots. Attached on the side with buckles. These could be washed under the faucet. I wanted one. I saw it on my friends' feet. Especially Naile's. Hers were shiny, new. I already had a pair [of boots], it was wrong to have another. I waited the whole winter for the rubbers although I knew it was not logical to get a second pair. . . . I kept looking at Naile's rubbers. (TR-F, 64)

As can be seen here, these objects of desire are sought in order to be and feel like one of the others, not for the object per se, the leather jacket, bike, or rubber boots.

The mimetic nature of desire is also obvious from the generally found imagery referring to things belonging to the canon of what it takes to live "the good life" in a modern consumer society. For our informants, whether in Turkey, Denmark, or the United States, cars, sailboats, vacations, beautiful homes, fine eating, global luxury brands are seen to belong to a good consumer life-these are the consumer society desirables. Such common imagery, despite the specific meanings given to objects depending on the cultural context, points to the constraints on the freedom of modern subjects and the context of modern subjectivities, as theorized by Foucault.

So we find that the desire for things is most often social, whether in the sense of inclusion, sociability, or mimesis. However, the social can also be displeasing and painfully restrictive, whether these restrictions involve imposed norms and societal constraints or the internalized constraints of self-control, as the next section reveals.

\section{Danger and Immorality}

Because desire is such a powerful emotional condition and one that opposes socially valued qualities of reason, rationality, and self-control, it is met with mixed feelings and sometimes even feared, akin to the paradoxical relations consumers express about technology (Mick and Fournier 1998). Acting on some desires is seen to involve socially or personally dangerous consequences, including immorality. The rebellious, unbounded, dangerous aspect of desire was more evident in the projectives than in the interviews and journals. This is itself indicative of the deep tensions involved. Even luscious foods and chocolate in the collages were seen by female informants to be shaded with danger and immorality as they are antithetical to social norms of self-control (see fig. 3). Desire is countered by concern with the physically dangerous, as in the case of unhealthy practices or addictive habits, or the socially dangerous, as shown in fears others will see us as indulgent, weak, immoral, or bad if we pursue these desires. Moral feelings of danger and transgression were framed more as matters of imbalance and lack of control in the Danish and Turkish contexts and as sin and guilt in the American context. In each context, these are powerful lenses for self-monitoring of desires.

Imbalance and Being Out of Control. The danger in the uncontrollability of desire is evident most clearly in a number of Danish informants' use of wildlife imagery and dangerous animals. One collage featured a lion, another both a lion and a shark. These animals, along with other demonic references, such as the mask depicted in figure 4 , refer to 


\section{FIGURE 3}

\section{TURKISH MALE DESIRE COLLAGE}

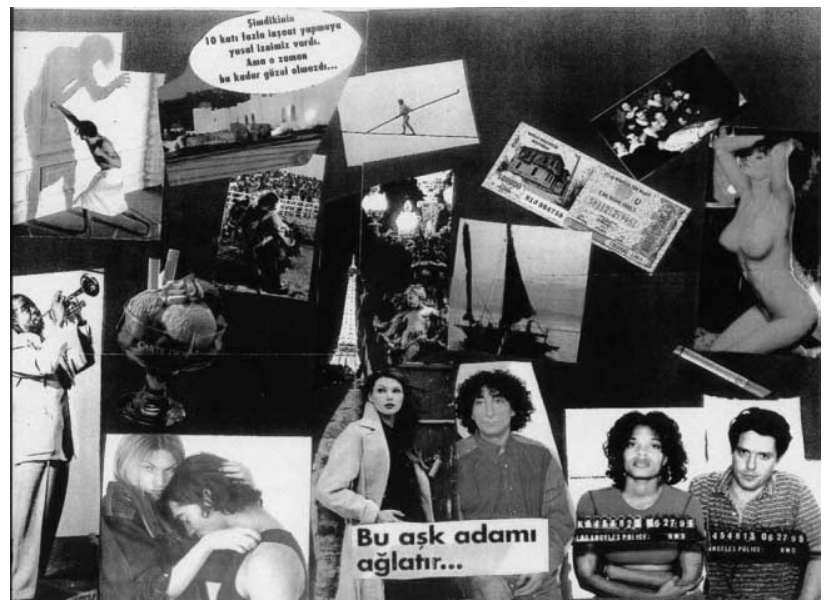

NOTE.-See the electronic edition of the journal for a color version of this figure.

the wild and demonic-simultaneously threatening and fascinating aspects of desire. Desire here is seen as an element of the human animality, a precultural force. Control of desire is felt to be impossible because desire is seen as inherently wild and beyond control. Desire, then, is about the impossible search for control over the uncontrollable. As explained by one informant, talking about his collage (fig. 5):

The texts symbolize the conflict between the animality of desire and human rationality. The phrase "obey your come" plays on the impossibility of following desire in the human world. Do as you please although I know you can't. (DKM, 25)

In this collage, there is also a reference to scorpions, interpreted as "predators you cannot trust." The maker of the collage in figure 5 said that desire ultimately is the urge to "tame the untameable," as illustrated by the animal trainer trying to make the woman jump through the ring of fire. This points to desire as a transporter of disorder to the normal cultural order, but which, if socialized and brought under control, loses its intensity and allure. In Jungian terms, the danger is the uncontrolled animus, regardless of whether it is reported by men or women in our study.

Unpredictable, uncontrolled, and irrational desire is also seen as involving the ways of a child. Significantly, many of the desired objects elicited are things desired in childhood. This is the state envisioned before socialization and rationalization inhibit us. Childishness is also seen in toys, cartoons, Aladdin, and Peter Pan in the collages (fig. 2) and in the description of feelings as "desiring like a child." Yet, just as children learn not to believe in Santa Claus and just as animals are domesticated in order to fit into normal human life, adults must attempt to tame their more intense desires and gain a sense of being in harmony with the world. The struggle with uncontrollable desires is seen in a number of our projective measures, particularly the collages and drawings. For instance, some of the Turkish depictions include a man caught in a spider web (interpreted by the informant as "desires enslave us"), a man trying to keep his balance on a tightrope (interpreted as "desires make a balanced life very difficult, but create excitement and fear"), and a man boxing with his shadow ("desire makes a man fight with himself. People fall into a conflict with their own principles due to their desires and experience inner turmoil"; see fig. 3). Explaining the collage's (fig. 3) inclusion of police photos of Hugh Grant and Divine Brown (also used in one Danish collage) after they were arrested for an act of public fellatio, a Turkish informant said, "Some desires are considered to be crimes but we dare to commit such crimes. Then there are bad consequences." Pictures of cigarettes and scenes from the films Basic Instinct, Dangerous Liaisons, and The Phantom of the Opera were similarly explained to involve dangerous pleasures.

We can also see, in the previous accounts, elements of transgression. Transgressing boundaries is itself found to be freeing and desirable, as with images James Dean ("the rebel") and a woman in a black coat ("extraordinary and rebellious") in Turkish collages (see figs. 1 and 2). An image of Rembrandt's Anatomy Lesson (see fig. 3) was explained as "desires and passions driving people to do forbidden things, rebelling against all authority, risking their lives."

\section{FIGURE 4}

\section{DANISH FEMALE DESIRE COLLAGE}

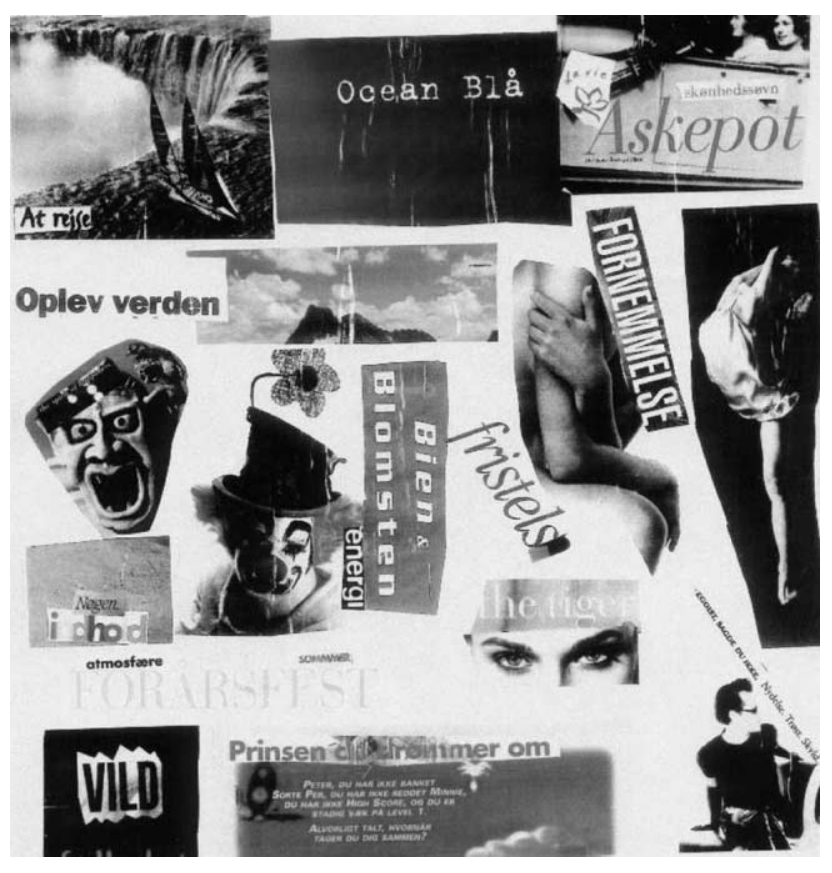

NotE.-See the electronic edition of the journal for a color version of this figure. 
FIGURE 5

\section{DANISH MALE DESIRE COLLAGE}

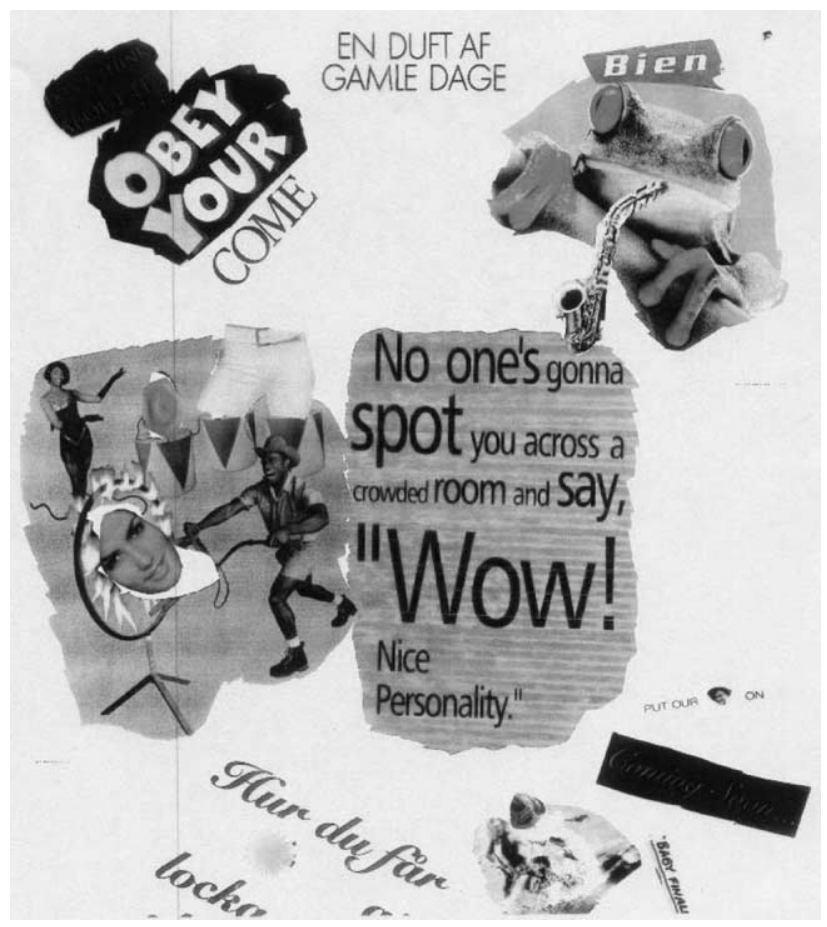

NOTE.-See the electronic edition of the journal for a color version of this figure.

The deep longing for courting danger is also underlined by some of the desire antonyms given, including tedium, blandness, and sameness. Such tedium was labeled "frogging" by one informant:

I live a proper life during the week, like normal people. I want a crazy life on the weekend. It is like, during the week, you live among the frogs. They think you are a frog too. But come weekend, you are a prince. Going to discos, techno, we have fun till morning. Different clothes, different lifestyle. You have to abide by society's norms and rules not to be excluded. The crazy nightlife breaks that monotony. To have a more dynamic life, I have to make more money. This means working more, more frogging. It was costly to have such a nightlife, [and] I started to work more to break that barrier. (TR-M, 24)

Like others who spend their weekends at raves, this man pursues his desire for the exciting and dangerous "crazy nightlife" to feel free, alive, and active. This may be seen as achieving a different sort of balance through opposing extremes rather than through a bland middle ground.

Guilt and Sin. From the American perspective, the lack of control of desire was seen as vaguely or explicitly evil or "sinful." One man told of a trip to Las Vegas with his girl- friend, pungent with the "scent of sin" emanating not only from gambling, cigarettes, alcohol, and sex but also from breaking society's rules. The U.S. collage images included rebels with guns pointed at the camera, a rose with thorns, and pictures of sumptuous foods juxtaposed with images of aerobic exercise (see figs. 6 and 7). These images were interpreted by the women who constructed them as reflecting their guilt about sinful desires for desserts, chocolates, sex, and alcohol (see Thompson and Hirschman 1995).

Addiction. In all three cultures, a frequent metaphor sometimes excusing loss of control or removing guilt is addiction. Devotion, obsessiveness, madness, enslavement, domination, craving, and losing oneself were all phrases used by the informants. Once again, the transgression is connected to ambivalent feelings of pleasure and guilt or feelings of being out of control or balance. For example, one American woman said, "I just need a pet fix here and there. It pacifies the feeling for a while." Another American woman who was relaying the saga of her desires for a mountain bike explained, "At this point, I knew I was hooked for good." Here the addiction metaphor excuses desire by saying, "It's a sickness; I can't help it." But the addiction label can also be a powerful cultural constraint on desire (Sassatelli 2001), as Turks and Danes reported. A Turkish man's collage with a prominent cigarette was interpreted as reflecting that "desire is like a cigarette: addictive and destructive." A Danish man was proud of controlling his transgressive desires:

I just sit and think about it, but I do not do it. I have too much morality to do it. I am not so mad that I succumb to my desire. I cannot get myself to do that. Not when I know that something has to be done. I do have some discipline after all. (DK-M, 28)

\section{FIGURE 6}

\section{TWO U.S. FEMALE COLLAGES}

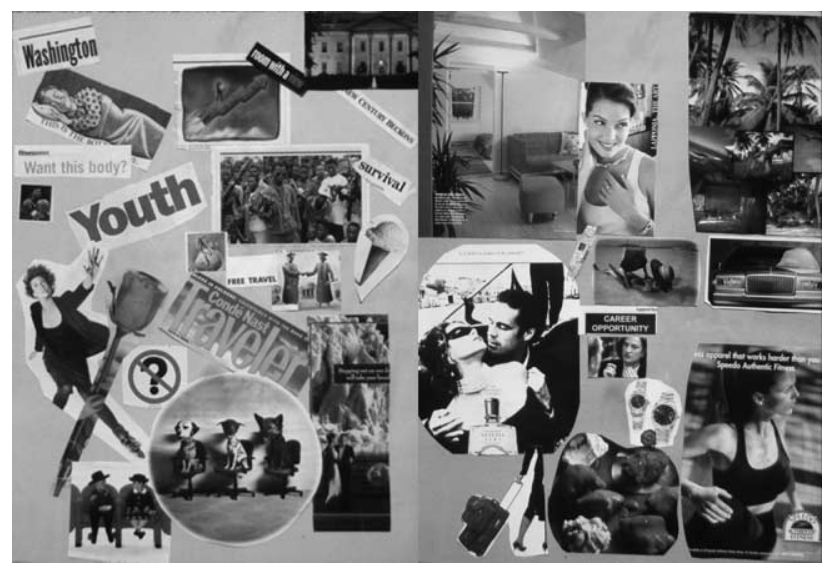

NotE.-See the electronic edition of the journal for a color version of this figure. 


\section{FIGURE 7}

\section{U.S. MALE DESIRE COLLAGE}



NotE.-See the electronic edition of the journal for a color version of this figure.

The morality invoked here (note the Protestant work ethic) controls but does not negate desire. Both the system of morality and the discipline invoked are ultimately social, according with Foucault.

\section{Distance and Inaccessibility}

Desire is also enhanced by the difficulty or improbability of obtaining the desired object, unless the object comes to be regarded as impossible to obtain or beyond any realistic hope. As expressed by one Dane: "How can I desire what I can just go and buy" (DK-M-27). Contrasting with the struggle for self-control, the struggle here is to obtain the object. Here a victory consists in acquiring rather than forgoing the desired object. For several Danish informants, this was seen as the defining characteristic of desire. The following is an example:

Desire, if you talk about desire for things or something else, it is often things that you cannot easily get. That is probably why it comes into being, that particular game, the unattainable and the longing. (DK-F, 25)

Another Danish informant referred to a maturing process through which desire develops from being oriented toward what are now relatively accessible material objects to possibly less tangible and less obtainable targets of desire. This connoisseurship of increasingly inaccessible desirables is also found among collectors (Belk 1995).

The projectives also indicate that the difficulty of reaching the object of desire is a defining aspect of desire. For example, Turkish drawings of desire included far away (insurmountable) mountains, which the informant said needed to be crossed to reach the desired object. Financial barriers, family objections, and the required effort, struggle, and sacrifices all keep distance between the consumer and the object of desire. "Distant," "far away," "difficult," and "effortful" were some of the words used to differentiate desire from want. This extends the table 1 distinctions. Generally, the more difficult it is to obtain, the more desirable the object is. The separation from the object increases the longing for it and the intensity of the emotion. Distance also keeps desire alive, but only so long as there is hope:

\begin{abstract}
I was in eighth grade. A friend in high school had a moped, we rode together sometimes. It was simply a love from deep inside me for the freedom the motorcycle provided. My desire reached enormous levels such that I was dreaming of mountains covered with identical orange colored bikes for as far as the eye could see. I would tell my parents about my persistent dreams and urge them to buy me a motorcycle, but they would always reject with great anger. Their anger would only cause me to see the dreams with increasing frequency. (TR-M, 25)
\end{abstract}

Similarly, a young Turkish girl recounted waiting for, and pursuing getting, an ankle bracelet for six years. In both cases, the parents did not buy nor allow the informants to buy these objects, yet these parental objections only served to fuel the desires. Although the distance, restraints, and inaccessibility themes emerged in each site, there were subtle cultural differences, with distance being greatest among the Turkish informants and least among the Americans. This helps us to understand the muting of desires among some lower-income Turks who felt that there was no hope of attaining desires.

For those with hope, the presence of restraints makes the desire stronger, more refined, and more persistent because it presents challenges to be heroically overcome. In so doing, the consumer hopes to be transformed from a weak character submitting to easy desires into a strong character overcoming obstacles. The long period over which some of these struggles to obtain desired objects take place is different from impulsive and compulsive consumption, as well as self-gifts. At the same time, contrary to Simmel, distance by itself is not motivating if there is no hope of overcoming barriers to acquiring desired objects. This results in a distinct cycle of desire.

\section{FINDINGS II: THE CYCLE OF DESIRE}

The entire process of consumer desire emerges as a cycle that has some similarities to those theorized by Campbell (1987) and Gould (1991a). Although desire is experienced as an emotion focused on a certain object, it is also seen as a process during which emotions change, especially with the realization of desires. The initial course of the cycle of desire is seen as involving self-seductive imagination and active cultivation of desire. Desire is cultivated and kept alive until the object is acquired or until it becomes clear that it is beyond hope, that it will never be acquired. 


\section{Self-Seduction}

The phenomenon of desire originates from and is perpetuated in the imagination, even if it seems that the thing desired has some magical ability to arouse these feelings in and of itself. Engulfed in our desires, we dwell on the objects we crave and, in so doing, elaborate and intensify our feelings. If the object of longing were sexual, this would be autoeroticism. We find a similar autoeroticism involving self-stimulation of desire for consumer goods. Belk (2001) also finds such self-seduction in the use of special interest magazines, with one informant directly comparing his eager search for new objects to desire within his special interest area (outdoor gear) to pornography. Many of our informants' references to particular mediated imagery, such as Singles, likewise show how the fantasies cultivated are not autonomous creations but, instead, are socially inspired, for instance, by media.

The process of enhancing emotions through imaginative elaboration often includes rehearsing what it will be like to obtain the object of desire. In the following account of desire for a fishing trip on the Madison River, the elaboration fueling the state of anticipation draws on media presentations and stories by mentors, as well as preparatory acquisitions.

I was 10 or 11 years old and was going on a vacation to Montana to fish in the Madison River with my father and family. I remember the feelings that I had when my father told me that the fish were large and plentiful, and if a fisherman knew how to fish, one could surely catch a trophy. I began to envision myself catching a large fish and proving my "masculinity." The young age made me believe that I had to prove myself in the "wilderness" if I were to truly become a man. There is no doubt that the Davy Crockett television episodes were a major contributor to this preadolescent fantasy. I began to purchase Outdoor Life magazines and spend all of my free time looking at the fishing stories. On Saturdays my father and I would take a trip to the sporting goods section of a local hardware store and purchase fishing equipment. The experience was great! I also began to buy or collect clothing that was fitting of a "true fisherman." A cousin loaned me his leather cowhide jacket, with long fringed leather arms and cuffs. My fishing pole was stored neatly behind my highly prized tackle box and fishing net. I was more than ready to go. When we arrived at the camping spot, I was delirious with excitement. We camped not far from the river, and I helped set up the camping tents. That evening would be my first encounter with the "Great Montana River," I told myself. . . . All the stories that I had heard and all the stories that I had read suggested that fish would "jump into your arms" if you had the right equipment. (USM, 28)

The adult now telling this tale of childhood desire recognizes that becoming an accomplished fisherman was a rite of passage that he had considerably enhanced with images from specialty magazines, TV, and western mythology. But far from being a passive victim of desire, he was an active participant who nourished and inflamed his own passion. Building expectations and excitement by rehearsing what it will be like to obtain the object of desire rests on fantasizing about the sensory as well as the social (e.g., becoming a man through a fishing experience). This is not merely the consumer complicity in seduction by marketers that Deighton and Grayson (1995) describe. The consumer's role in self-seduction is considerably more active than this. The social object seduces us (Baudrillard 1983), but we want to be seduced, and we play an active role in the seduction. However much it may seem to beckon, some consumers, like the would-be fisherman, implicitly or explicitly recognize that they have generated some of the allure of the object.

\section{Longing}

When desire is realized, it is quelled, if only until another focal object of longing is found. Such a cycle of desire was described by an American pet lover, a Turkish car lover, and a Dane longing for an apartment:

My gerbil turned out to be a boy and [my sister's] was a girl, and when soon her gerbil had babies and one of our gerbils ate the babies, I decided I wanted a dog. That oh-sofamiliar longing ache in my stomach returned, and the entire desire ordeal started again. This feeling has not disappeared as my family has been through one gerbil, two canaries, three hamsters, two fish, and five dogs throughout the past 14 years. (US-F, 22)

It was a great effort to get my driver's license. I worked parttime jobs and saved all of my earnings to buy a second-hand car, but could never have enough money. My parents promised to buy one for my graduation. All my friends had cars. I thought I had to have one too. Upon graduation, instead of a second-hand car, they surprised me with a brand-new one; a good model, fast. . . . Now that I have it, it is no longer the most important thing in life for me. Maybe I got used to it. Now there is another fire awakening in me. I want a faster, better car. I have a sports car, but I'd like a Cabrio. If I have that, I might then want a plane. (TR-F, 25)

What I wanted the most for the last three years was an apartment. My desperation grew and grew. Then, when [I] finally found the perfect apartment, things couldn't go fast enough. I could finally sleep a whole night through without speculating about this, but now I used a lot of time speculating on how to decorate it. It had to be perfect. And it became almost perfect. I calmed down inside myself and things started to get back into the usual routines, daily life reappeared. A daily life with a peace of mind until the next exigency appears. (DK-F, 25)

In each case, the cycle of desire is seen to follow an inevitable course: desire-acquisition-reformulation of desire, ad infinitum. Once the desired object is possessed, it loses 
its ability to remain an object of desire. If there is joy in realizing a desire, it is short-lived and transforms itself into routine, boredom, or even negative feelings about the oncebeloved object. Disillusioned consumers seldom seem to learn, and once achieved, desire is commonly refocused on some new desideratum. This is similar to Campbell's (1987) "spirit of modern consumerism" that dooms us to a perpetual, but ultimately fruitless, quest for consumption euphoria.

For some experiences, however, desire can be recycled. In the "frogging" story above, the desirable nightlife is longed for every weekday and repeated every weekend. Similarly, in going skiing, dining at a favorite restaurant, or making love to the beloved again and again, the renewable experience remains an object of renewable desire. The same applies to cigarettes and other addictive objects. This finding provides a twist on the cycle of desire and differentiates it from Campbell's (1987) notion. Here the desire remains because of its satisfaction and the wish to repeat this satisfaction, rather than because of any disappointment with the object of desire. Thus, the realization of desire can lead to either a boredom-initiated cycle of desire focused on a new object or a fulfillment-initiated attempt to recycle desire in order to repeat these pleasures.

\section{Processes Sustaining, Accelerating, and Reinitiating Desire}

Desire to Desire. Whether the realization of desires leads to a cycling or recycling of desire, the reinitiation of desire appears to involve a basic desire to desire. An American woman recalling her history of desires captured this longing:

Christmas morning had finally come. I was 16 years old at that time. . . . Each year my parents would buy us one large present. . . . I decided that I would not ask for anything, and I would leave the big decision up to my mom's creativity. What I secretly wanted that year, possibly because I knew my parents would never go for it, was a big, white, stuffed teddy bear. This was no ordinary bear, it was five-feet tall-much taller than me at the time. . . . It cost over $\$ 100.00$. I would hug it every time I walked by it. My mother had found out about my love for this bear, and even though she thought it was childish and expensive, she had bought it for me to make my Christmas special. Now as I look back on my life, I realize that I would often develop a longing for something I knew I couldn't have. The bear was simply something I wanted because I thought was out of my reach. Christmas morning was very special, but I couldn't help but feel a little disappointed in my gift at that time because it was the desire to have the bear that I needed, not the bear. (USF, 22)

Still, there remains a conundrum. If we harbor a desire for desire, it might seem that indefinite postponement of desire fulfillment could allow us to remain in this pleasurable condition.

You see, the question is whether you actually get this feeling or whether it has all been a dream, and when it is realized, it is not as fantastic as you thought it would be. Perhaps those dreams should never be realized. (DK-F, 26)

For many years I wanted to have a tape recorder, but that was a dream. Last year, on my birthday, my mom gave me one as a surprise. But it was so strange. I had wished for it constantly, and now it was in my hands. But, it no longer meant anything. I mean, desiring it was much better. (TR-F, 25)

Here we see the importance of distance and lack of control (having $=$ controlling) for sustaining desire. But although the largely positive state of desire can be prolonged for a time by delaying its realization, we also see that, if delayed indefinitely, the accompanying state of hope is likely to fade.

Fear of Being without Desire. The desire to desire is sustained by fears of being without desire, as suggested by projective responses envisioning the absence of desire. One projective task involved sketching what two sculptures entitled "Desire" and "Not Desire" might be like. Whereas "Desire" was characterized as round, smooth, and harmonious, "Not Desire" was confused, angular, and harsh appearing. Drawings of "Not Desire" included depictions such as a graveyard; boarding a ship and leaving loved ones behind; people crawling to polluted factories; a dark, dirty alley with poor, dirty people and trash bins; and a man doing push-ups with a gun pointed at his head. Similarly, antonyms elicited for desire included both negative terms (e.g., hatred, loathing, fear, disgust) and terms depicting emptiness (e.g., death, dullness, apathy, indifference, laziness, hopelessness). Another informant found a similar blandness in his portrait of life without the extremes of desire:

That would be a robot who gets up in the morning, shaves, and goes to work, who smiles, and who plays badminton every Tuesday afternoon at four. And who goes home, watches television, and talks to his/her friends about things that have not happened while they are trying to make it sound funny even though it is not. It is a kind of solitude that you are not even aware of. That must be the worst of all. (DKM, 23)

Informants also described someone's feelings before, during, and after getting something they strongly desired. The descriptions of states after obtaining the object of desire were to a large extent nonpositive. This included negative feelings from disappointment with the object or its maintenance (let down, burdened, worried, unappreciative, jealous, remorseful, anxious, scared, fearful of loss) as well as feelings of emptiness due to the disappearance of the hopeful state that preceded acquisition (bored, frustrated, discour- 
aged, unsure, without goals, confused, lazy, empty, without interest, indifferent). In the case of intangibles, these feelings were more positive (craving and longing for the next incident, affection, appreciation, adoration, admiration) due to the hopeful anticipation of the next encounter. Clearly, the positive, if dangerous, emotion of desire is felt as more positive in its anticipation than in its realization or its aftermath, contrary to utilitarian and need-based views.

What the images of the absence of desire suggest most is that to be without desire is to be without hope. To desire and to have some likelihood of achieving this desire is to hope for an ideal object. To desire is to envision a transformed and ideal self. Accordingly, to the modern subject, who is often described as restless, to be without desire is seen as being a state of hopelessness tantamount to death.

Hope. Desire coupled with the chance for realizing a desire creates a state of hope that is itself pleasurable. When there appears to be little or no chance of realizing a desire, the resulting state of hopelessness is one that is negative: the person is forlorn, depressed, desolate, despairing, let down, discouraged, disappointed, resigned, hurt, or bitter, depending in part on whether the reason the desire is frustrated or denied is internal or external and whether it is seen to be the result of chance, someone else's intentional or unintentional actions, or some failing on the part of the person who harbors the desire. It appears to be the positive nature of hope that leads to a desire for desire. That is, underwriting the desire for desire is the hope for hope. Without the hope of obtaining the focal object, desires dissolve into mere wishes or impossible fantasies. They remain alluring but are hard to sustain as fervently as desires that are coupled with a hope of achieving them.

Hope is not the same as anticipation of acquiring a desired object, which can also be pleasurable. Unlike hope, anticipation has been dealt with in terms of outcomes that are certain (e.g., Lowenstein 1987). But, just as zero probability of acquiring a desired object extinguishes hope, so, too, does certainty that it will be acquired. The sources of pleasure are distinct in hope and anticipation. For children, Santa is hope. Similarly, it can be said that escatological theology is about hope rather than anticipation. This is generally consistent with MacInnis and de Mello (2002, p. 7), who define hope as yearning for "an outcome appraised as uncertain, yet possible."

With hope, a central construct in both antiquity (e.g., Pandora's Box) and Christian tradition, we also edge closer to a motivational understanding of desire. Because hope relates to the chance for success in realizing a desire (Stotland 1969), there may be an opportunity to increase hopefulness by making desire realization a goal and working toward achieving this goal. Such work could entail, as our informants discussed, earning money, saving money, devoting time, sacrificing by forgoing other things, persuading others who are blocking the realization of a desire, preparing ourselves for attaining the object, being patient, and being worthy and deserving, depending on the cultural context, the subject, and the object. That is, we work to achieve desires by exploring ways to make the distant object more accessible. These actions nurture hope. Thus, when the realization of the desire is temporarily frustrated, the combined affect of stimulating both hope and desire makes the current state tantalizingly near, but still just out of reach.

On the other hand, frustration and disappointment are likely to set in when hopes are dashed or disappear, with the realization that acquiring the desired object, such as an almost-acquired house or a car, is not going to happen. In such cases, it is not that the desire has diminished but, rather, that the hope of achieving this desire has died. If there appear to be no alternative ways of fulfilling the desire, it may eventually diminish in strength as well or a seemingly more obtainable object of desire takes its place in occupying the person's thoughts and providing a new focus of desire and hope.

Hope and desire remain two distinct, but related, states. Desire is the emotional attraction to some object, but hope is the felt possibility or likelihood of achieving a desire. The cycle of desire is thus accelerated by the desire to desire, the hope for hope, and the fear of being without desire. Realization of desire results in reinitiation of the cycle of consumer desire, focused on some new object. This cycle of desire is depicted in figure 8. The cycle depicted is further animated by the tensions of seduction and morality, to which we now turn.

\section{DISCUSSION AND CONCLUSIONS}

Consumer desire is overwhelmingly felt to be a powerful emotion, overshadowing other motivational constructs usually referenced in consumer research, such as wants. It is also primarily positive, although our informants generally recognize the delicate balance between pursuing one's desires and transgressing internalized limitations on what is appropriate social behavior. Desire, like fire, is a wonderful servant but a horrifying master. Likewise, our informants are generally aware that the satisfaction of desire is far from guaranteed and the journey is often better than the arrival. This is the micro desire of figure 8 . We now turn to a more macro, societal, view of desire.

Although the micro processes of desire are prominent in all three sites, it is clear that not only is desire expressed and enacted in culturally specific ways but also the mere possibility of experiencing desire is culturally bound. Commonalities among objects desired (e.g., luxury cars, boats, homes) point to the existence of a globalizing consumer culture with a common imagery of the material basis of the good consumer life. But, as lived or perceived experiences, even such commonalities are always culturally contextualized.

Underlying the manifest focus on specific objects is the desire for social relations and particular reactions from valued others and for becoming an entirely different person. Tales of desires for fishing the Madison River as a rite of passage into manhood, a black Fazioli piano for social and self-esteem, or a Porsche for the power it conveys in society are demonstrations of the social behind the personal. This longing for the social positions and relationships that are 
FIGURE 8

THE CYCLE OF DESIRE

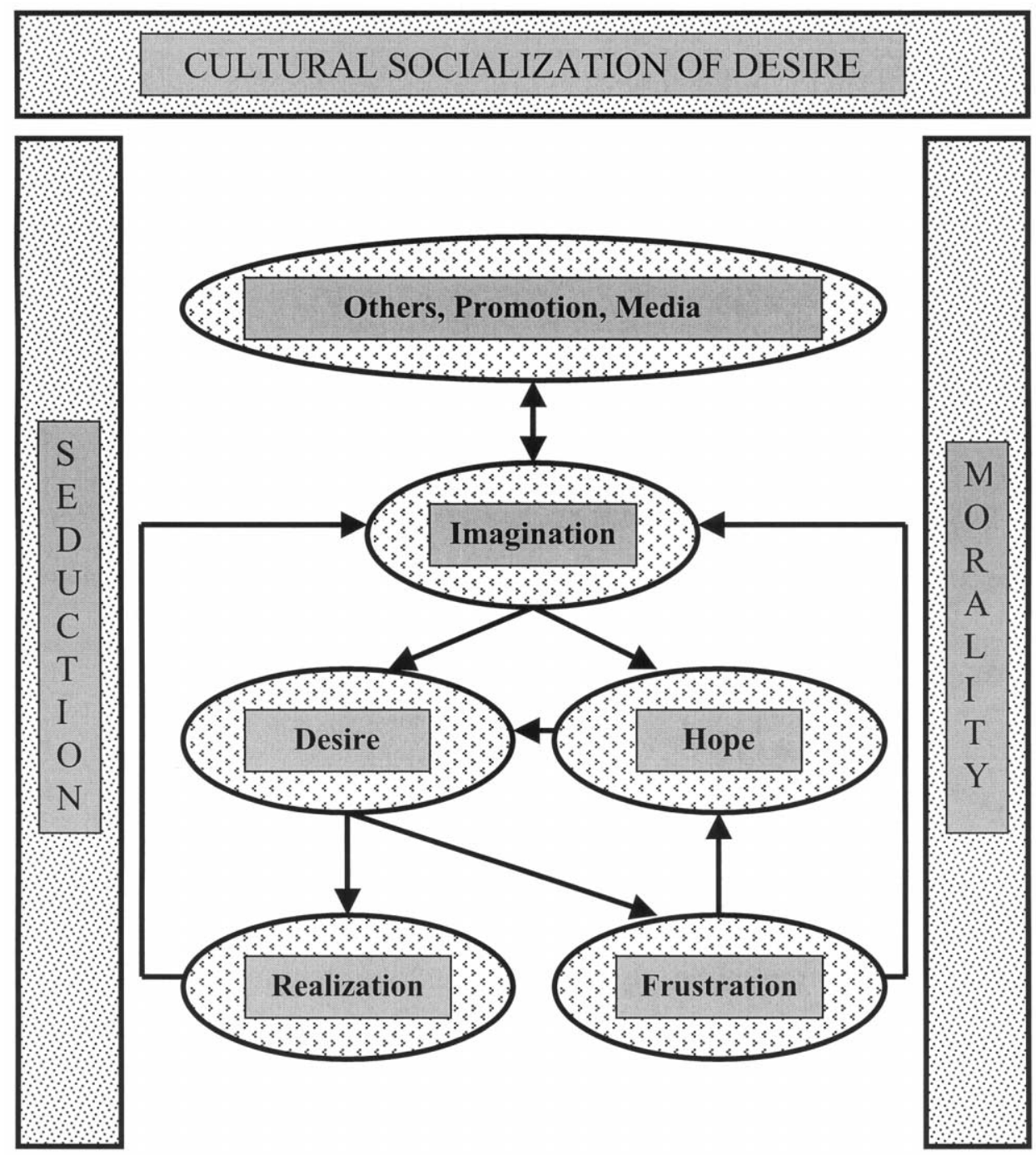

foundations for the value of desired objects also became evident with the projective responses to swimming in a sea of desired objects. Citations not of things but of people suggest that the sea of desire is a sea of human connections.

Thus, either explicitly or implicitly, our informants suggest that the objects that transfix them are hoped to be conduits to, rather than surrogates for, love, respect, recognition, status, security, escape, or attractiveness. These are the social relations we desire, consciously or subconsciously, beneath the objects that we find so compelling. The value of the objects that we focus our longing upon inheres less in the object or in a Lacanian search for childhood love than in the culture. The hope for hope that an altered state of being may result keeps the cycle of desire moving. Desires are nurtured by self-embellished fantasies of a wholly different self, and they may be stimulated by external sources, in- cluding advertising, retail displays, films, television programs, stories told by other people, and the consumption behavior of real or imaginary others. But we find that the person who feels strong desire has almost always actively stimulated this desire by attending, seeking out, entertaining, and embellishing such images. The desires that occupy us are vivid and riveting fantasies that we participate in nurturing, growing, and pursuing, through self-seduction.

In seeking out and clinging to our consumer desires, the inherently impractical and passionate longing for an altered state of being, fused with conflicting emotions and dangers, is fundamentally different from the more logical and mechanistic view envisioned by homeostatic models of need satisfaction as deficit reduction, as well as different from a false versus true needs dichotomy or a necessity-luxury dichotomy. Nor is it simply variety seeking in pursuit of some 
optimal level of stimulation and arousal. Desires are at once more profound and more fanciful than this. With the exception of older lower-income Turkish informants (mostly from rural areas) who see themselves as spectators to modern subjectivity, our informants see themselves pursuing projects that will make their lives worth living. They passionately seek joy, happiness, bliss, and something infinitely better than they now have. Their desires are profoundly sensual and corporeal experiences akin to physiological cravings. For their desires are embodied as well as mental.

Whether the object of desire is a pair of shoes, a dream house, or a trip to Paris, we seem quite capable of investing considerable meaning and emotion in our images of these objects. The perpetually renewed state of desire is exciting, dangerous, tempting, promising, delicious, and compelling. Our fear of being without desire reveals our attachment to the state more than to the outcome of desire. To desire is to live, to hope, to be alive. With imagery co-shaped by capitalistic markets and consumerist ideologies, much of our consumer behavior appears better characterized as the pursuit not only of desired objects, but of desire itself.

However, the emergent understanding of desire as active construction of consumer passion does not imply that the consumer creates a state of longing that flows unimpeded into consumption of the desired object. The choice of the object of desire emerges as a resolution of certain tensions experienced by the consumer. These tensions are between and within the fields that we label seduction and morality. The fields of seduction and morality flesh out how the construction of desire and the object of desire entail, simultaneously, a melding of personal strategy and the dictates of the society. Society becomes embodied and embedded in the subject. Seduction concerns the bodily and imaginative experience of desire for the person, and morality concerns the anticipated social consequences of harboring and acting on this desire. Whether a desire is sustained by hope is a function of both the accessibility of the object and the balance between the tensions of seduction and morality. These tensions constitute the dynamic forces sustaining hope and legitimizing desire or else reigning in and controlling desire. The paradoxes implicit in our findings (e.g., freedom vs. addiction, social acceptance vs. transgressive pleasure, enjoyment vs. danger, not beyond hope yet difficult to achieve) reflect the conflict between seduction and morality and generate the dynamism of desiring cycles.

\section{Seduction}

Seduction, including self-seduction, is a key part of the motivating force of desire. As noted by Baudrillard (1979, pp. 134-135), "The seducer, does he not end up by getting lost himself in his own strategy like in a labyrinth of passions? Does he not invent it to get lost?" This image of getting lost in a labyrinth of passions parallels our discussion of control. Even though desire may include a yearning for control (of the objects of desire), we also, like Baudrillard's seducer, want to lose control to our desires. Nevertheless, we are not apt to recognize that we are our own seducers.
Instead, as evident in informant accounts, through the mediated imagery of advertising, media, and other cultural intermediaries co-shaping our sensations and imaginations, we externalize the power of desire as residing in the object itself, employing Falk's (1994) strategy for justifying our desires by framing the object's attractiveness as irresistible. This is more akin to the interpersonal model of romantic love discussed by Ahuvia (1992) and Belk and Coon (1993), except that, rather than a human lover, the romantic other is the consumer good. So, too, as Sontag (1979, p. 44) observes, is the desire to desire a reflection of romanticism. Not only do we lose control but we also abandon ourselves to the romanticized object of our longing. If we find love at first sight, the inanimate object we imagine to call out to us for affection, purchase, and possession may result in impulse purchasing (Rook 1987; Rook and Hoch 1985). But our desire for desire and hope for hope may result in a different consumer state where we relish the unfulfilled, but achievable, longing.

Just as interpersonal passion depends on yearning for the sensations of smell, touch, and the sight of the other, the sensory anticipation of consumer objects fuels the imagination and enhances desire. Sensation and imagination feed each other, increasing the titillation of longing. It is these same bodily senses that provoke moral fears of the destructive power of obsessive passion, and it is this embodied mind that energizes the self-creative agent to negotiate with the social and the moral while co-constructing the subject and the object of desire.

\section{Morality}

The dynamics of seduction exist in a state of tension with morality. On the one hand, seduction is framed by societal determinations of what are desirable objects. On the other hand, the potentially destructive aspects of both appetitive sensuality and romantic imagination of a dangerous act bolster the transgression inherent in some desires. The transgression or going out of bounds that excites the desire comes with feelings of danger, framed as guilt, sin, imbalance, or loss of control, depending on the social context. The selfseduced consumer's passionate longing encounters the social order, duty, and sociability, necessitating a resolution that is regarded as moral or legitimate.

Seeking culturally shaped transformation by transgression, otherness, and dangerous objects is constitutive of desire. As is evident in the collages, the American story about the trip to Las Vegas, the Turkish frogging story, and the Danish counteranalogy of the robot, transgression is not just dangerous and negative but is also seen by some as necessary to feel alive. At the same time, consumers attempt to make their daily lives moral. Morality prescribes the pleasurable conduct of consumption. As Campbell (1990) argues, individuals are moral beings who are "reluctant to engage in acts which they cannot satisfactorily justify to themselves" (p. 42). They attempt, at least historically, to conduct themselves to fulfill and assure character ideals. Although Odysseus had himself physically bound in order 
to resist the seduction of the Sirens' song, modern consumers rely on the internalized restraint that results from internalizing social morality. Consumers draw from various ethics prevalent in their cultures to make their consumption moral or legitimate (Ger and Belk 1999; Sassatelli 2001). The moral dilemmas that we find in consumer desires resonate with Foucault's (1985) treatment of desire as an ethical problem. As self-managing subjects, we moderate our consumption acts and refine our consumption desires in order to feel or become an ethical person.

\section{Culture and the Socialization of Desire}

Our data imply that, on one hand, the vitality and pleasure of desire rest on breaking the order, monotony, routines, limits, and rules, but on the other hand, self-control, moral conduct, sociality, and mimesis are themselves desirable. These tensions are neither solely between the individual's desires and social or self-constraints nor only between desires and sin. The tension is also between the individual's own social, affective, moral desires (as in the desire for sociability) and more transgressive desires. This is an internal personal struggle with a social basis, echoing $\mathrm{Ba}-$ taille's (1967) idea about interdictions and their transgression as constitutive of sociality and individuality. The seductive means of securing freedom and pleasure also court the danger that may cause us to reign in these desires. The paradoxical tensions our study uncovered include fun versus guilt, pleasure versus health, freedom versus the enslavement of addiction, vitality versus balance, self-control versus sin, and rationality versus uninhibited animality and childishness. The Western child at Christmas time, with which we began, is relatively free of moral constraints and is therefore liberated desire and hope incarnate. But for adults, these dialectical tensions keep consumer desire alive and powerful, just as the dialectical tensions of possession, surrender, yearning, and danger keep alive the destructive as well as life-affirming potential of sexual desire.

The different play of these forces can be seen in the differences in the cultures studied. Rather than just EastWest differences or Islamic-Christian differences, we find more complex cultural differences. Turkish and Danish informants showed similarities in what they consider to be danger. An established versus emerging market economy difference was observed in the types of otherness desired by the American and Danish informants versus the Turkish informants. An Old World-New World difference was obtained within one site: the older lower-income Turkish informants with rural backgrounds felt that they could not entertain desires, reflecting an ethics of duty and family over the individual. Other research, such as that of Collier (1997) in Spain and Costa (1988) in Greece, suggests that younger generations exposed to global market capitalism may well develop modern subjectivities that overpower this traditional subjugation of individual desire. This is not simply a case of learning to want things but a more fundamental shift of moralities. With marketization, a shift is to be expected in subjectivities, from a focus on the family and duty to a focus on the individual. Global flows of people, technology, money, media, and products (Appadurai 1990) and transnational connections in economic, political, and cultural domains (Hannerz 1996) rapidly diffuse market capitalisms throughout the world, aided by the global flow of ideologies, such as the consumerist ideology. Consumer desire is likely to be manifested differently in different cultures and times, depending on socialization and cultural intermediaries such as advertising, marketing, and media, as well as on different modernities and modern subjectivities. With global capitalism and its ideology of consumerism, the human potential of desire (for otherness, danger and morality, and sociability, hope to hope, desire to desire) is likely to be channeled onto objects of consumption. The connections to wider techniques of domination such as market capitalism and its institutions and discourses of modernity, capitalism, individuality, and independence, propagated by capitalism's tools such as marketing, advertising, and media are not difficult to see in the discourses of the informants. On the other hand, desire to desire and paradoxes between seduction and morality not only keep the consumer alive, but, in turn, also keep consumer cultures and consumerist ideologies alive.

Even though we find cultural differences on the seduction side of desire in terms of what are considered to be socially acceptable objects of desire, we find more profound differences on the morality side, where the different cultures studied sustain different ways of defining as well as legitimizing desire. Ger and Belk (1999) more directly investigated how people in different societies morally justify materialistic desires, and they found legitimations based on culturally variable ethics. The discourse of desire is interwoven with culturally specific discourses of ethical behavior.

The consumer is no mere pawn, either in the web of seduction or in the web of social relations. Through the desire to desire, we allow and prepare our self to be seduced. We need only make ourselves accessible and open to becoming enchanted by the abundant promises of the marketplace. Our imaginations do the rest. However, to be able to pursue a desire, and sometimes even to feel it and conceive of it as a desire, we must feel that we have the right and justification to do so, implying a modern subjectivity.

These findings and interpretations are limited to the sites and the informants we studied and the methods we used. Longitudinal case studies may better delineate the processes and the outcomes of the cycle of desires. A more systematic sample of age groups may provide a different interplay of desire, seduction, and morality. The location, age, and income differences among Turkish informants suggest that moralities may differ by background. The experience of consumer desire requires a modern subject who is likely to live in a market society or be urban and young in a marketizing society. Thus it would be interesting to examine how consumer desires are muted and negotiated in other ways in other contexts. Our findings hint that a more systematic analysis of gender differences may help to counteract stereotypes of women as being more likely to succumb to desires. And cultural differences detected suggest that 
further work is warranted among cultural contexts of hope and despair in the way people are included in or excluded from globalizing consumer society.

\section{THEORETICAL IMPLICATIONS AND FURTHER RESEARCH}

For the single consumer, desire, as a lived phenomenon, may pertain to only a small number of objects in the daily life. However, the experience of passionately desiring such objects is critically informative for the study of consumption. For it shows how we are still enchanted and desire to be enchanted, despite the jading that occurs in a culture of abundance, and it provides glimpses of the restless energy with which most of us pursue the development of our consumption possibilities. Our finding that, in consumer societies, consumer desires entail hope and are vitally energizing also explains the despair of people who cannot afford hopeful desire. Exposed to a consumer society where desiring is life-affirming, those who can neither afford nor hope to consume must either resolve to not desire or else let consumption exist only in magic and fantasy. This gives a new meaning to relative deprivation in its encounter with enchantment.

This investigation of the phenomenon of desire both supports and revises the contention of Campbell (1987) and others that consumers experience an intense longing for desire itself. We do find that consumers experience a desire for desire and regard its absence as tantamount to death. It is the absence of desire rather than Campbell's specification of disappointment at our purchase's inability to live up to the fantasy we had of it or Gould's (1991a) specification of the decline of momentary consumption bliss that appears to reinitiate the cycle of desire. Intangibles and addictions for which we find recycling desire around the same object strengthen and further differentiate our conclusion that it is the desire to desire rather than disillusionment that energizes this the cycle of desire.

Nevertheless, the desire for the state of desire appears to be linked to a state of hopefulness. Although immediate consumer desires focus on goods and services that are just out of reach, the deeper longing seems to be for a transformation of self and for the love and admiration of others. Even though it is consumption-based, the self-transformation we hope for is ultimately nonmaterial and less subject to moral criticism in contemporary societies. This potential is basic to our informants' experience of desire

Our findings lend some support to various anthropological theorizing related to the notion of desire, for example, desire for desire as a general human potential and mimetic desire as a basis for establishing social values. Mimetic desire also underlines the deeply social and cultural character of desire, where consumer desire is an affirmation of belonging in a globalizing consumer culture. Here, our data suggest both the importance of specific cultural contexts for desired objects (e.g., desiring life in nature vs. metropolitan life) and the specific cultural and social contexts for incorporating global consumer culture through different moralities (e.g., transgression vs. sin and guilt) and seduction mechanisms (e.g., external media, friends, and repeatable experiences).

The dimensions and processes of desire may reinform prior research thrusts in consumer research involving rites of intensification, flow, play, magic, self-reward, sacrifice, self-gifts, motivation, emotion, satisfaction, media effects, self-concept, and voluntary simplicity. Because hope was not the intended thrust of our research, the constructs of hope and hopelessness and their relationship to desire deserve further attention. O'Shea (2002) has recently theorized a more explicit link between desire and pursuit of the sacred. Secular hopes attached to passionate consumer desires suggest that consumption has become a source of inspiration, transcendence, and even redemption. To desire is to feel vitally alive and hold back the void of death. Our desire for Otherness may be seen as a quest for transcendent sacredness. Despite prior discussion of the sacred in consumption (Belk et al. 1989), we have scarcely begun to consider these phenomena.

In the more thoroughly investigated area of passionate consumption, our findings both support and amend prior consumer research. We find that consumer desires differ from impulse buying, compulsive consumption, high involvement purchases, and magic. We identify a type of passionate consumption that is not captured fully by any of these. High-involvement consumption has been treated as involving rational calculation that opposes desire. Impulse buying is immediate, whereas desire involves longing, patience, and sacrifice. The idealization of a particular object of desire and sustained longing differentiate it from both compulsive consumption and self-gifts. Although desire shares with magical consumption (Arnould and Price 1993; Arnould et al. 1999) the readiness of the consumer, struggle or work, and active and creative consumers, there are also many differences: desire is not the experience but the longing, the search for magic; although magical experience generates a transformation, desire is an aspiration for transformation; desire need not involve rites and formulas and has more internal sorcerers. Compared to Arnould and Price's (1993) ready consumers of river-rafting magic cooperating with the river guide sorcerer, the self-enchantment in consumer desire relies more directly on the consumer's imagination.

Consider the implications of the present model of desire for prior consumer research involving marketing narratives creating temptation (Thompson et al. 1994) and impulse purchasing in response to a product that seems to call out our name (Rook 1987). Both perspectives are redolent of the Garden of Eden story of the snake (read: marketer) tempting Eve. But what such accounts neglect is the role of self-seduction and the internal struggle between seduction and morality. They seem instead to reflect the tensionresolving rationalization that the consumer is overcome by irresistible external forces. Furthermore, the biblical account provides one reification of morality and raises important 
questions of gender bias in these moral accounts. We find men at least as susceptible to consumer seduction as women.

Self-seduction implies a twist on Foucault's (1984a, $1984 b, 1985,1986)$ self-care and the techniques of the self. Our findings imply that self-managing subjects are not only self-restraining but also self-seducing. Modern subjects appear to engage in self-monitoring to assure that they do not seem foolish but also to assure that they do not seem backward and dead to the world.

If, as seems plausible in a consumer society, consumers now attach their major sources of hope to acquiring desired consumption objects, we might ask about the status of alternative sources of hope that do not involve consumer desire and their links to consumption. What is the relationship between work achievements and our consumption achievements, beyond the income that ties the two? Does religion as a source of hope and meaning present itself as an alternative or an extension of consumer society? How does desire negotiate the relation between having and being? And if, as Campbell (1990) argues, an internal focus on character as a source of identity is a thing of the past, can we now look only externally for meaning and hope? Investigation of such broader issues is one agenda for future consumer research.

In explicating the mechanisms of the cycle of desire, selfseduction, the desire for desire, the hope for hope, the tensions of seduction and morality, and the vital excitement of desire, we believe we have made progress in understanding the nature of the intertwined personal and cultural forces that bear on our consumption passions. The seduction-morality tensions that keep the cycle moving and our desire for desire imply that consumer desires are not likely to decrease as long as capitalist markets and consumerist ideologies channel hope and desire onto consumer objects. Rather than envisioning reduced consumption as a necessary sacrifice, opponents of consumerism might do better by attempting to envision equally compelling sources of desire and hope.

The social nature of desire implies that preferences of consumers are far from being independent. Yet, choice models assume that preferences of consumers act as individuals (Bagozzi 2000). The mimetic aspect of desire creates difficulties for using individual attitude or intention measures to predict adoption of new products whose use will be visible. The notion of desire we have derived suggests that the appeal of the desired object is not inherent in the object itself. Models that begin with preferences for product attributes or benefits are therefore problematic. The consumer, individually and jointly, has a role in constructing the object of desire, within a social context. What makes consumer desire attach to a particular object is not so much the object's particular characteristics as the consumer's own hopes for an altered state of being, involving an altered set of social relationships.

Our findings suggest that views on luck, deservingness, and just consumption inform and sustain desire in a way that is likely to be culturally variable. This suggests that cross-cultural work on these moral concepts will be important. Basic existential beliefs are implicated in our struggles between seduction and morality. Barber's (1996) framing of Jihad versus McWorld and Huntington's (1993) framing of the clash of civilizations critically invoke such beliefs and their ties to consumption.

Despite its negative and dangerous aspects, modern subjects seem to have neither the will nor the desire to overcome the consumption-oriented version of desire to desire. Consumer desire, in all its destructive capacities, is also constructive and creative. So seduction and morality define the complex intermingling of personal and social forces shaping our consumption. The vital passion of desire that emerges in overcoming constraints and abandoning moral self-control is felt as an overpowering and irresistible urge that cannot be tamed by reason. Once such desire is fixed on an object, everything else fades in importance, and the ardor and object of our desire transfixes us. We have hope and purpose in life. We are vital, alive, and invigorated. We have auto-aroused ourselves to a state of near rapture. It is this recognition that is missing in goal- or need-based consumer research. Although space and the limits of our research do not allow exploring the various suggested topics here, it is our desire and hope that this attempt to explicate the felt nature of consumer desire will stimulate a wide variety of such work.

\section{[David Glen Mick served as editor and Eric J. Arnould served as associate editor for this article.]}

\section{REFERENCES}

Ahuvia, Aaron (1992), "For Love of Money: Materialism and Product Love," in Meaning, Measure, and Morality of Materialism, ed. Floyd W. Rudmin and Marsha Richins, Provo, UT: Association for Consumer Research, 188-198.

Ainslie, George (1985), "Beyond Microeconomics: Conflict among Interests in a Multiple Self as a Determinant of Value," in The Multiple Self, ed. Jon Elster, Cambridge: Cambridge University Press, 133-175.

Appadurai, Arjun (1990), "Disjuncture and Difference in the Global Cultural Economy," Theory, Culture, and Society, ed. Mike Featherstone, Vol. 7, London: Sage, 295-310.

Arnould, Eric J. and Linda L. Price (1993), "River Magic: Extraordinary Experience and the Extended Service Encounter," Journal of Consumer Research, 20 (June), 24-45.

Arnould, Eric J., Linda L. Price, and Cele Otnes (1999), "Making Consumption Magic: A Study of White-Water River Rafting," Journal of Contemporary Ethnography, 28 (1), 33-68.

Bagozzi, Richard P. (2000), "On the Concept of Intentional Social Action in Consumer Behavior," Journal of Consumer Research, 27 (December), 388-396.

Bakhtin, Mikhail ([1965] 1968), Rabelais and His World, Cambridge, MA: MIT Press.

Barber, Benjamin (1996), Jihad vs. McWorld: How Globalism and Tribalism Are Reshaping the World, New York: Ballantine.

Bataille, Georges ([1949] 1967), La part maudite, Paris: Editions de Minuit.

Baudrillard, Jean (1972), Pour une critique de l'économie politique du signe, Paris: Gallimard. (1979), De la seduction, Paris: Galilée. (1983), Les strategies fatales, Paris: Grasset. 
Baumeister, Roy (2002), "Yielding to Temptation: Self-Control Failure, Impulse Purchasing, and Consumer Behavior," Journal of Consumer Research, 28 (March), 670-676.

Belk, Russell W. (1983), "Worldly Possessions: Issues and Criticisms," in Advances in Consumer Research, Vol. 10, ed. Richard P. Bagozzi and Alice M. Tybout, Ann Arbor, MI: Association for Consumer Research, 514-519.

(1985), "Materialism: Trait Aspects of Living in a Material World," Journal of Consumer Research, 12 (3), 265-280.

- (1991), "The Ineluctable Mysteries of Possessions," Journal of Social Behavior and Personality, 6 (June), 17-55.

(1995), Collecting in a Consumer Society, London: Routledge.

_ (1997), "Romanian Consumer Desires and Feelings of Deservingness," in Romania in Transition, ed. Lavinia Stan, Aldershot: Dartmouth Press, 191-208.

- (2001), "Specialty Magazines and Flights of Fancy: Feeding the Desire to Desire," in European Advances in Consumer Research, Vol. 5, ed. Andrea Groeppel-Klein and Franz-Rudolf Esch, Berlin: Association for Consumer Research, 197-202.

Belk, Russell W. and Gregory Coon (1993), "Gift-Giving as Agapic Love: An Alternative to the Exchange Paradigm Based on Dating Experiences," Journal of Consumer Research, 20 (December), 393-417.

Belk, Russell W. and Janeen Arnold Costa (1998), "The Mountain Man Myth: A Contemporary Consuming Fantasy," Journal of Consumer Research, 25 (December), 218-240.

Belk, Russell, Güliz Ger, and Søren Askegaard (1996), "Metaphors of Consumer Desire," in Advances in Consumer Research, Vol. 23, ed. Kim P. Corfman and John G. Lynch, Jr., Provo, UT: Association for Consumer Research, 368-373.

(1997), "Consumer Desire in Three Cultures: Results from Projective Research," in Advances in Consumer Research, Vol. 24, ed. Merrie Brucks and Debbie MacInnis, Provo, UT: Association for Consumer Research, 24-28.

- (2000), "The Missing Streetcar Named Desire," in The Why of Consumption, ed. S. Ratneshwar, David Glen Mick, and Cynthia Huffman, London: Routledge, 98-119.

Belk, Russell W., Melanie Wallendorf, and John Sherry (1989), "The Sacred and the Profane in Consumer Behavior: Theodicy on the Odyssey," Journal of Consumer Research, 15 (June), $1-38$.

Born, Georgina (1998), “Anthropology, Kleinian Psychoanalysis, and the Subject in Culture," American Anthropologist, 100 (2), 373-386.

Campbell, Colin (1987), The Romantic Ethic and the Spirit of Modern Consumerism, London: Blackwell. (1990), "Character and Consumption: A Historical Action Theory Approach to the Understanding of Consumer Behaviour," in Culture and History, ed. O. Lofren, Aarhus: Akademisk Forlag, 37-48.

Castoriadis, Cornelius (1975), L'institution imaginaire de la société, Paris: Seuil.

Celsi, Richard L., Randall L. Rose, and Thomas W. Leigh (1993), "An Exploration of High-Risk Leisure Consumption through Skydiving," Journal of Consumer Research, 20 (June), 1-23.

Collier, Jane Fishburne (1997), From Duty to Desire: Remaking Families in a Spanish Village, Princeton, NJ: Princeton University Press.

Costa, Janeen (1988), "Systems Integration and Attitudes toward Greek Rural Life: A Case Study," Anthropological Quarterly, 61 (April): 73-90.
Crawford, Robert (1984), “A Cultural Account of 'Health': Control, Release, and the Social Body," in Issues in the Political Economy of Health Care, ed. John B. McKinlay, New York: Tavistock, 60-103.

Csikszentmihalyi, Mihaly and Eugene Rochberg-Halton (1981), The Meaning of Things: Domestic Symbols and the Self, Cambridge: Cambridge University Press.

Deighton, John and Kent Grayson (1995), "Marketing and Seduction: Managing Exchange Relationships by Managing Social Consensus," Journal of Consumer Research, 21 (4), 660-676.

Douglas, Mary and Baron Isherwood (1979), The World of Goods: Towards an Anthropology of Consumption, New York: Norton.

Dupuy, Jean-Pierre (1979), "Le signe et l'envie," in L'enfer des choses, ed. Paul Dumouchel and Jean-Pierre Dupuy, Paris, Editions du Seuil, 17-134.

Elliott, Anthony (1992), Social Theory and Psychoanalysis in Transition: Self and Society from Freud to Kristeva, Oxford: Blackwell.

Elliott, Richard (1997), "Existential Consumption and Irrational Desire," European Journal of Marketing, 31 (3-4), 285-296.

Ewen, Stuart (1976), Captains of Consciousness: Advertising and the Social Roots of Consumer Culture, New York: McGrawHill.

Falk, Pasi (1994), The Consuming Body, London: Sage.

Firat, A. Fuat and Alladi Venkatesh (1995), "Liberatory Postmodernism and the Reenchantment of Consumption," Journal of Consumer Research, 22 (December), 239-267.

Foucault, Michel (1984a), "On the Geneaology of Ethics," in The Foucault Reader, ed. Paul Rabinow, New York: Pantheon, 340-372.

- (1984b), "What Is Enlightenment?" in The Foucault Reader, ed. Paul Rabinow, New York: Pantheon, 32-50. (1985), The History of Sexuality, Vol. 2, The Use of Pleasure, New York: Random House.

(1986), The History of Sexuality, Vol. 3, The Care of the Self, New York: Random House.

- (1988a), "The Political Technology of Individuals," in Technologies of the Self: A Seminar with Michel Foucault, ed. Luther H. Martin, Huck Gutman, and Patrick H. Hutton, London: Tavistock, 145-162.

- (1988b)"Technologies of the Self," in Technologies of the Self: A Seminar with Michel Foucault, ed. Luther H. Martin, Huck Gutman, and Patrick H. Hutton, London: Tavistock, 16-49.

Freedberg, Anne (1993), Window Shopping: Cinema and the Postmodern, Berkeley: University of California Press.

Freund, Julien (1971), "Théorie du besoin, " in L'année sociologique, Paris: Presses Universitaires de France, 13-64.

Ger, Güliz (1997), "Human Development and Humane Consumption: Well-Being beyond the Good Life," Journal of Public Policy and Marketing, 16 (1), 110-125.

Ger, Güliz and Russell W. Belk (1996), "I'd Like to Buy the World a Coke: Consumptionscapes of the 'Less Affluent World,'" Journal of Consumer Policy, 19 (3), 1-34.

- (1999), "Accounting for Materialism in Four Cultures," Journal of Material Culture, 4 (July), 183-204.

Girard, René (1977), Violence and the Sacred, Baltimore: Johns Hopkins University Press.

(1987), Things Hidden since the Foundation of the World, Stanford, CA: Stanford University Press.

Gould, Stephen J. (1991a), "An Asian Approach to the Understanding of Consumer Energy, Drives, and States," in $R e$ - 
search in Consumer Behavior, Vol. 5, ed. Elizabeth Hirschman and Jagdish N. Sheth, Greenwich, CT: JAI Press, 33-59. - (1991b), "The Self-Manipulation of My Pervasive, Perceived Vital Energy through Product Use: An Introspective Praxis Perspective," Journal of Consumer Research, 18 (September), 194-207.

Hannerz, Ulf (1996), Transnational Connections, London: Routledge

Haug, Wolfgang F. (1986), Critique of Commodity Aesthetics: Appearance, Sexuality, and Advertising in Capitalist Society, Minneapolis: University of Minnesota Press.

Hoch, Stephen J. and George F. Lowenstein (1991), "Time Inconsistent Preferences and Consumer Self Control," Journal of Consumer Research, 17 (March), 492-507.

Holbrook, Morris (1993), "Nostalgia and Consumption Preferences: Some Emerging Patterns of Consumer Tastes," Journal of Consumer Research, 20 (September), 245-256.

Holbrook, Morris B., Robert W. Chestnut, Terrence A. Oliva, and Eric A. Greenleaf (1984), "Play as Consumption Experience: The Roles of Emotions, Performance, and Personality in the Enjoyment of Games," Journal of Consumer Research, 11 (September), 728-739.

Holbrook, Morris B. and Elizabeth C. Hirschman (1922), "The Experiential Aspects of Consumption: Consumer Fantasies, Feelings, and Fun," Journal of Consumer Research, 9 (September), 132-140.

Holt, Douglas B. (1995), "How Consumers Consume: Toward a Typology of Consumption Practices," Journal of Consumer Research, 22 (June), 1-25.

Huntington, Samuel (1993), "The Clash of Civilizations," Foreign Affairs, 62 (3), 22-49.

Joy, Annamma and Alladi Venkatesh (1994), "Postmodernism, Feminism, and the Body: The Visible and the Invisible in Consumer Research," International Journal of Research in Marketing, 11 (September), 333-357.

Klein, Richard (1993), Cigarettes Are Sublime, Durham, NC: Duke University Press.

Laborit, Henri (1976), Eloge de la fuite, Paris: ed. Robert Laffont.

Lacan, Jacques (1992), The Seminar of Jacques Lacan, bk. 7, The Ethics of Psychoanalysis, 1959-1960, ed. Jacques-Alain Miller, New York: Norton.

Leach, William (1993), Land of Desire: Merchants, Power, and the Rise of a New American Culture, New York: Random House.

Lefebvre, Henri (1991), The Production of Space, Oxford: Blackwell.

Lehtonen, Turo-Kimmo (1999), “Any Room for Aesthetics? Shopping Practices of Heavily Indebted Consumers," Journal of Material Culture, 4 (3), 243-262.

Levy, Sidney J. (1959), "Symbols for Sale," Harvard Business Review, 17 (July-August), 117-124.

- (1960), "Symbols of Substance, Source, and Sorcery," Art Direction (January).

- (1986), "Dreams, Fairy Tales, Animals, and Cars," Psychology and Marketing, 2 (2), 67-81.

- (1999), Brands, Consumers, Symbols, and Research: Sidney J. Levy on Marketing, compiled by Dennis W. Rook, Thousand Oaks, CA: Sage.

Lowenstein, George (1987), "Anticipation and the Valuation of Delayed Consumption," Economic Journal, 97 (September), 666-684.

MacCannell, Dean (1987), “'Sex Sells': Comment on Gender Images and Myth in Advertising," in Marketing and Semiotics:
New Directions in the Study of Signs for Sale, ed. Jean Sebeok, Berlin: de Gruyter, 521-531.

MacInnis, Deborah J. and Gustavo de Mello (2002), “The Concept of Hope and Its Relevance to Consumer Behavior," working paper, Department of Marketing, University of Southern California, Los Angeles, CA 90089

McCracken, Grant (1988), Culture and Consumption: New Approaches to the Symbolic Character of Consumer Goods and Activities, Bloomington: Indiana University Press.

Mick, David Glen and Michelle DeMoss (1990), "Self-Gifts: Phenomenological Insights from Four Contexts," Journal of Consumer Research, 17 (December), 322-332.

Mick, David Glen and Susan Fournier (1998), "Paradoxes of Technology: Consumer Cognizance, Emotions, and Coping Strategies," Journal of Consumer Research, 25 (September), 123-143.

Miller, Daniel, ed. (1995), Worlds Apart, London: Routledge. - (1998), A Theory of Shopping, Ithaca, NY: Cornell University Press.

O'Guinn, Thomas and Ronald Faber (1989), "Compulsive Buying: A Phenomenological Exploration," Journal of Consumer Research, 16 (September), 147-157.

Öncü, Ayse (1997), “The Myth of the 'Ideal Home' Travels across Cultural Borders to Istanbul," in Space, Culture and Power: New Identities in Globalizing Cities, ed. Ayse Öncü and Petra Weyland, London: Zed, 56-72.

O'Shea, Anthony (2002), "Desiring Desire: How Desire Makes Us Human, All Too Human," Sociology 26 (November), 925-940.

Reekie, Gail (1993), Temptations: Sex, Selling, and the Department Store, St. Leonards, NSW, Australia: Allen \& Unwin.

Richardson, William (1987), "Ethics and Desire," American Journal of Psychoanalysis, 47 (4), 296-301.

Richins, Marsha L. and Peter H. Bloch (1986), "After the New Wears Off: The Temporal Context of Product Involvement," Journal of Consumer Research, 13 (September), 380-385.

Richins, Marsha L. and Scott Dawson (1992), "A Consumer Values Orientation for Materialism and Its Measurement: Scale Development and Validation," Journal of Consumer Research, 19 (December), 303-316.

Rook, Dennis (1985), "The Ritual Dimension of Consumer Behavior," Journal of Consumer Research, 12 (December), 251-264. (1987), "The Buying Impulse," Journal of Consumer Research, 14 (September), 189-199.

- (1988), "Researching Consumer Fantasy," in Research in Consumer Behavior, Vol. 3, ed. Elizabeth C. Hirschman and Jagdish N. Sheth, Greenwich, CT: JAI, 247- 270.

Rook, Dennis and Stephen J. Hoch (1985), "Consuming Impulses," in Advances in Consumer Research, Vol. 12, ed. Morris B. Holbrook and Elizabeth C. Hirschman, Provo: Association for Consumer Research, 23-27.

Sahlins, Marshall (1996), "The Sweetness of Sadness: The Native Anthropology of Western Cosmology," Current Anthropology, 37 (June), 395-428.

Sassatelli, Roberta (2001), "Tamed Hedonism: Choices, Desires, and Deviant Pleasures," in Ordinary Consumption, ed. Jukka Gronow and Alan Warde, London: Routledge, 93-106.

Schouten, John W. and James H. McAlexander (1995), "Subcultures of Consumption: An Ethnography of the New Bikers," Journal of Consumer Research, 22 (June), 43-61.

Sherry, John F., Jr. (1983), "Gift Giving in Anthropological Perspective," Journal of Consumer Research, 10 (September), 157-168.

Sherry, John F., Jr., Mary Ann McGrath, and Sidney J. Levy 
(1995), "Monadic Giving: Anatomy of Gifts Given to the Self," in Contemporary Marketing and Consumer Behavior: An Anthropological Sourcebook, ed. John F. Sherry, Jr., Thousand Oaks, CA: Sage, 399-432.

Simmel, Georg ([1900] 1978), The Philosophy of Money, trans. Tom Bottomore and David Frisby, London: Routledge \& Kegan Paul.

Slater, Don (1997), Consumer Culture and Modernity, Cambridge: Polity.

Sontag, Susan (1979), Illness as Metaphor, New York: Vintage.

Stewart, Susan (1984), On Longing: Narratives of the Miniature, the Gigantic, the Souvenir, the Collection, Baltimore: Johns Hopkins University Press.

Stocker, Michael (1986), "Akrasia and the Object of Desire," in The Ways of Desire: New Essays in Philosophical Psychology on the Concept of Wanting, ed. Joel Marks, Chicago: Precedent, 197-215.

Stotland, Ezra (1969), The Psychology of Hope, San Francisco: Jossey-Bass.

Thompson, Craig J. and Elizabeth C. Hirschman (1995), "Understanding the Socialized Body: A Poststructuralist Analysis of Consumers' Self-Conceptions, Body Images, and Self-Care Practices," Journal of Consumer Research, 22 (September), 139-153.
Thompson, Craig, Howard R. Pollio, and William B. Locander (1994), "The Spoken and the Unspoken: A Hermeneutic Approach to Understanding the Cultural Viewpoints That Underlie Consumers' Expressed Meanings," Journal of Consumer Research, 21 (December), 432-452.

Tiger Lionel (1992), The Pursuit of Pleasure, Boston: Little, Brown.

Turner, Victor and Edith Turner (1978), Image and Pilgrimage in Christian Culture: Anthropological Perspectives, New York: Columbia University Press.

Veblen, Thorstein (1899), The Theory of the Leisure Class: An Economic Theory of Institutions, New York: Macmillan.

Wilk, Richard R. (1997), "A Critique of Desire: Distaste and Dislike in Consumer Behavior," Consumption, Markets, and Culture, 1 (2), 177-196.

Williams, Raymond (1980), Problems in Materialism and Culture, London: NLB.

Williams, Rosalind (1982), Dream Worlds: Mass Consumption in Late Nineteenth-Century France, Berkeley: University of California Press.

Zaltman, Gerald and Robin A. Coulter (1995), "Seeing the Voice of the Customer: Metaphor-Based Advertising Research," Journal of Advertising Research, 35 (July-August), 5-51. 